\title{
Knowledge and Learning:
}

\section{Global Empowerment}

Proceedings of the Management,

Knowledge and Learning

International Conference 2012

20-22 June 2012

Celje · Slovenia

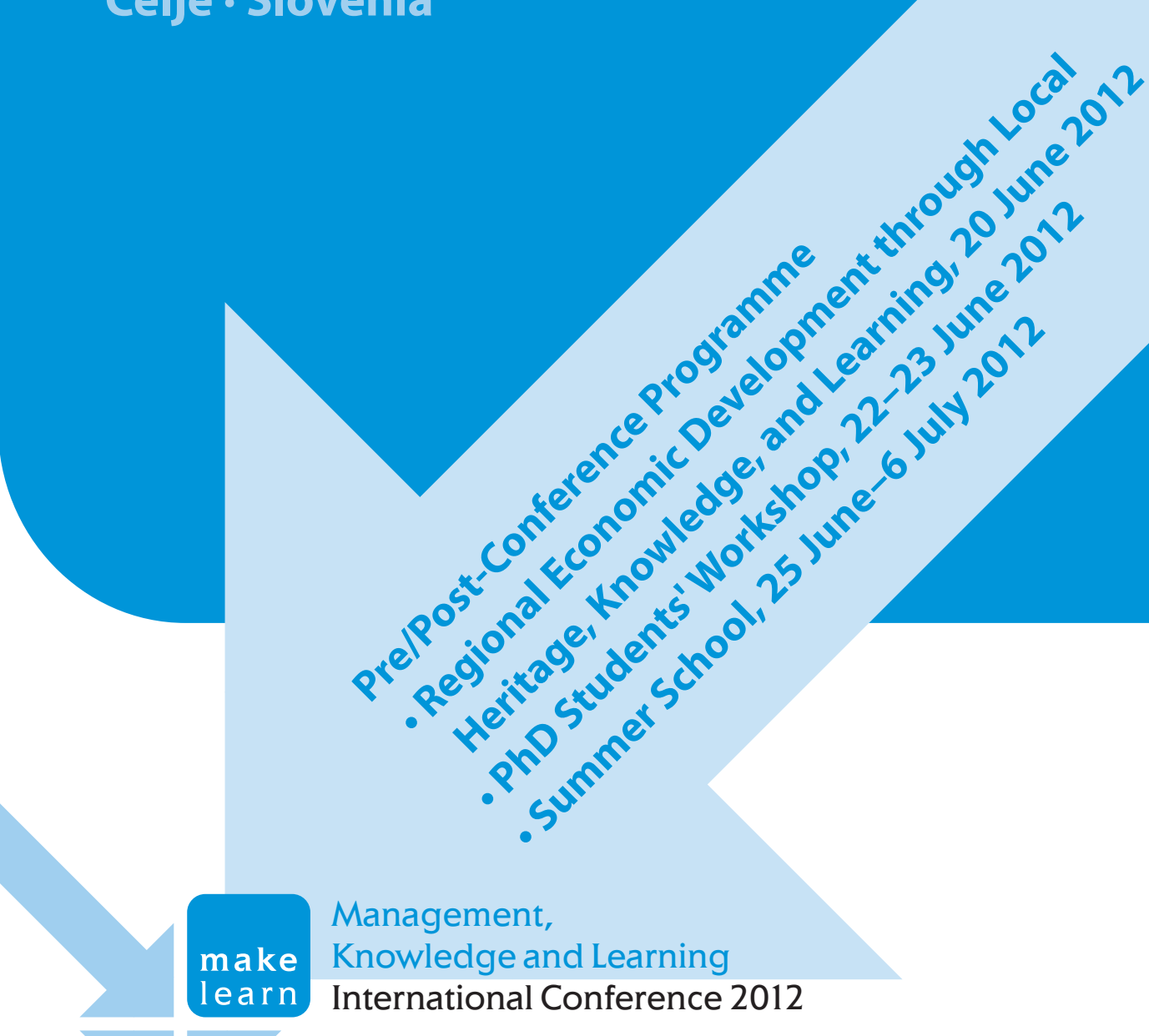




\title{
Table of Contents
}

\author{
Welcome Address 3
}

Conference Boards 4

Conference Aims 6

Keynote Speakers 7

Academic Leadership Forum 9

Editors' Panel with Exhibition of Journals 10

Business Excellence Forum 12

Conference Programme 13

\section{Sessions 15}

Pre-Conference Programme 36

Post-Conference Programme 37

\section{Calls for Papers 38}

Index 44

Organizers and Sponsors 50

MakeLearn 2012: Knowledge and Learning; Global Empowerment

Proceedings of the Management, Knowledge and Learning

International Conference 2012; 20-22 June 2012, Celje, Slovenia

Organized by

International School for Social and Business Studies, Slovenia

\section{Co-organizers}

Kasetsart University, Thailand

Maria Curie-Skłodowska University, Poland

Al Akhawayn University, Morocco

\section{Co-financed by}

Slovenian Research Agency

\section{Edited by}

Valerij Dermol, Nada Trunk Širca, Goran Đaković and Urška Lindav

\section{Published by}

International School for Social and Business Studies

Mariborska cesta 7, 3000 Celje, Slovenia

June $2012 \cdot 250$ copies

(c) 2012 International School for Social and Business Studies

The author is responsible for the linguistic correctness of his or her paper.

CIP - Kataložni zapis o publikaciji

Narodna in univerzitetna knjižnica, Ljubljana

005:001.101(082)(086.034.4)

MANAGEMENT, Knowledge and Learning International Conference (2012; Celje)

Knowledge and learning: global empowerment [Elektronski vir] : proceedings of the Management, Knowledge and Learning International Conference 2012, 20-22 June 2012, Celje, Slovenia / [organized by International School for Social and Business Studies ; edited by Valerij Dermol ... et al.]. - El. zbornik. - Celje : International School for Social and Business Studies, 2012. - (MakeLearn, ISSN 2232-3309)

Dostopno tudi na: http://www.issbs.si/press/ISBN/978-961-6813-10-5/MakeLearn2012.pdf

ISBN 978-961-6813-09-9 (CD-ROM) ISBN 978-961-6813-10-5 (pdf)

1. Gl. stv. nasl. 2. Dermol, Valerij

262210048 


\section{Welcome Address}

It is a great honour and pleasure to welcome you to the Management, Knowledge and Learning - MakeLearn International Conference 2012. The conference is a great opportunity to make your contribution to and share the most recent developments in the field of knowledge management with Slovenian and foreign experts.

International School for Social and Business Studies (ISSBS) is organising MakeLearn 2012 in cooperation with foreign partners, i.e. Kasetsart University, Thailand, Maria Curie-Skłodowska University, Poland, and Al Akhawayn University in Ifrane, Morocco. The conference deals with the management of knowledge and learning in businesses and other organisations, particularly with issues brought forward by the current financial and economic crisis. We believe that knowledge drives innovation and economic recovery, hence the focus of the conference on knowledge as a business opportunity.

In recent years, knowledge management has been given a lot of attention in businesses and other organisations as well as in rapidly increasing numbers of scientific and expert publications. After the first conference MakeLearn 2011, the ISSBS encourages the discussion and exchange of knowledge also through the new International Journal of Management, Knowledge and Learning.

We welcome 165 conference participants and authors of the papers from 24 countries. We would also like to thank everyone who helped us to organise MakeLearn 2012, and wish you all a successful conference and a pleasant stay in Celje.

Dr. Srečko Natek, Dean of the ISSBS

with co-organisers

Kasetsart University, Thailand

Maria Curie-Skłodowska University, Poland

Al Akhawayn University, Morocco

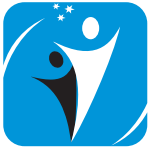

Mednarodna fakulteta

za družbene in poslovne študije

International School

for Social and Business Studies

Celje $\cdot$ Slovenija 


\section{Conference Boards}

\section{Conference Board}

Dr. Srečko Natek, Dean, International School for Social and Business Studies, Slovenia, General Chair

Dr. Nada Trunk Širca, International School for Social and Business Studies, Slovenia, Conference Chair

Dr. Binshan Lin, BellSouth Corporation Professor in Business Administration at College of Business Administration, Louisiana State University, USA, Conference Director

Dr. Bordin Rassameethes, Dean, Faculty of Business Administration, Kasetsart University, Thailand, Co-Organiser

Dr. Zbigniew Pastuszak, Director of the Institute of Management, Faculty of Economics, Maria Curie-Skłodowska University, Poland, Co-Organiser

Dr. Mohamed Dahbi, Dean, Al Akhawayn University in Ifrane, Morocco, Co-Organiser

\section{Programme Board}

Dr. Valerij Dermol, International School for Social and Business Studies, Slovenia, Programme Chair

Dr. Pornthep Anussornnitisarn, Deputy Director, International Graduate Program in Industrial Engineering, Faculty of Engineering, Kasetsart University, Thailand

Dr. Zaid Bouziane, Assistant Professor of Communication Studies and Undergraduate Programmes Coordinator, School of Humanities and Social Sciences, Al Akhawayn University in Ifrane, Morocco

Dr. Anca Draghici, University of Timisoara, Romania

Dr. Dejan Hozjan, International School for Social and Business Studies, Slovenia, and Faculty of Education, University of Primorska, Slovenia

Dr. Andrej Koren, National School of Leadership in Education, Slovenia

Dr. Dušan Lesjak, International School for Social and Business Studies, Slovenia, and Faculty of Management, University of Primorska, Slovenia

Dr. Agnieszka Leszczynska, Faculty of Economics, Maria Curie-Skłodowska University, Poland

Dr. Miroslaw Loboda, the CEO of the UMCS Development Foundation, Maria Curie-Skłodowska University, Poland

Dr. Radosław Mącik, Faculty of Economics, Maria Curie-Skłodowska University, Poland

Dr. Karim Moustaghfir, School of Humanities and Social Sciences, Al Akhawayn University in Ifrane, Morocco

Dr. Haruthai Numprasertchai, Associate Dean of Academics, Faculty of Business Administration, Kasetsart University, Thailand

Dr. Daniela Pasnicu, Spiru Haret University, Romania

Dr. Kongkiti Phusavat, Director, Center of Advanced Science in Industrial Technology, Kasetsart University, Thailand 
Dr. Anna Rakowska, Head of the Enterprise Management Department, Faculty of Economics, Maria Curie-Skłodowska University, Poland

Dr. Cezar Scarlat, University Politehnica of Bucharest, Romania

Dr. Agnieszka Sitko-Lutek, Vice Dean of the Faculty of Economics for Research and International Cooperation, Maria Curie-Skłodowska University, Poland

Dr. Elzbieta Skrzypek, Head of the Quality and Knowledge Management Department, Faculty of Economics, Maria Curie-Skłodowska University, Poland

Dr. Urszula Skurzynska-Sikora, Faculty of Economics, Maria Curie-Skłodowska University, Poland

Dr. Seweryn Spalek, Faculty of Organization and Management, Silesian University of Technology, Poland

Dr. Abdouli Touhami, Faculty of Arts and Humanities, University of Sousse, Tunisia

Dr. Bartłomiej Zinczuk, Faculty of Economics, Maria Curie-Skłodowska University, Poland

Dr. Egon Žižmond, Faculty of Management, University of Primorska, Slovenia

Dr. Daniela de Carvalho Wilks, Universidade Portucalense, Portugal

\section{Organising Board}

Goran Đaković, Head of Research Department, International School for Social and Business Studies, Slovenia, Head of Organising Board

The administrative and technical staff from ISSBS: Mia Kočevar, Katja Kolenc, Jasmina Mohorko, Marko Smrkolj, and Danijel Žabić. 


\section{Conference Aims}

International scientific conference MakeLearn 2012 encourages the sharing of most recent findings in the field of management of knowledge and learning in business and other organizations (e.g. public institutions, non-profit organizations). In particular, this year's conference focuses on the issues of knowledge and learning as global empowerment tools, which is reflected in the subtitle of the conference 'Knowledge and Learning: Global Empowerment.'

These are the concepts usually associated with individual, organisational and social performance. Practitioners and researchers believe they have a potential to build sustainable competitive advantages and core capabilities of both organisations and society; only the individuals, organisations and societies able to sustain innovation, develop high-tech products and capitalise new knowledge will be successful. It is becoming more and more obvious that knowledge and learning are an important source of global power. MakeLearn 2012 conference stresses the importance of topics related to knowledge and learning at the personal level and at the level of organisations and societies. 


\section{Education Directed on Requirements of Business}

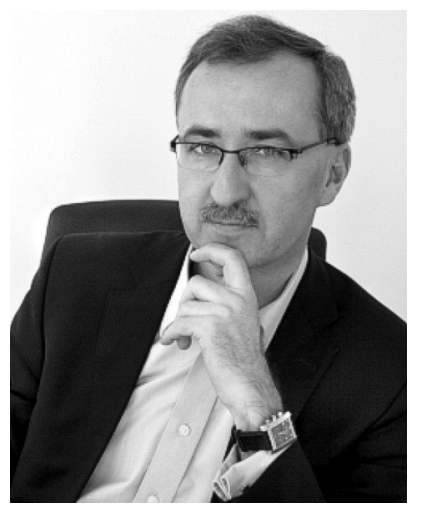

\section{Maciej Maniecki}

Founder and owner of IT companies Solet and WebChili; president of the Enterprise Council for the Lublin Region (Rada Przedsiębiorczości Lubelszczyzny), Poland

Thursday, 21 June $2012 \cdot 9.45-10.15$

Maciej Maniecki graduated from Technical University of Warsaw in 1987. In 1990 he and his group of friends, set up SAFO LLC. Initially, the company employed 9 staff members who developed software. In 2005 the company employed approximately 150 staff members becoming one of the largest providers of ERP systems on the domestic market. In 2007 Maciej Maniecki decided to merge with three other Polish IT companies. This is how Asseco Business Solutions came into being in which he held the position of Vice President of the Management Board. In 2007 Asseco Business Solutions went public and is now listed on the Warsaw Stock Exchange. The company allocated substantial funds acquired on selling and became one of the biggest Polish IT companies employing in 2009 over 800 employees. In 2009 he came to the conclusion that his mission was completed and upon terminating his membership in the Company's Management Board he became President of its Supervisory Board. At present he is the founder and owner of two IT companies: Solet specialises in Bl systems and WebChili in Internet solutions. In addition to working in the capacity of investor and advisor in some of the companies which he has established he is also President of Rada Przedsiębiorczości Lubelszczyzny (Enterprise Council for the Lublin Region). Established in 2007 as an association of local entrepreneurs, he was one of its founding fathers. The primary aim of the Enterprise Council for the Lublin Region is ongoing support of the regional economic development. Since 2009 Maciej Maniecki is a member of the Convention at the Maria Curie-Skłodowska University. In January 2011 he became a member of the Convention at Technical University of Lublin. He is also an advisor to President of Lublin Krzysztof Żuk since December 2010. 


\section{How to Foster Excellence in Slovenian Higher Education?}

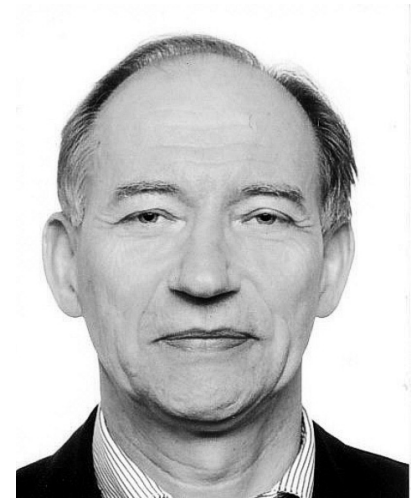

Dr. Milan Vodopivec

World Bank, USA; International School for Social and Business Studies, Slovenia, and Faculty of Management, University of Primorska, Slovenia

Friday, 22 June 2012 • 11.00-11.30

Dr. Milan Vodopivec finished his PhD in the field of economics at the University of Maryland, USA. His research interests include mainly the labour market, social benefits and education, resulting in more than 100 scientific and professional articles in reputable foreign scientific journals. In 1989 he joined the World Bank in Washington, where he participated in several studies of labour markets in countries in transition, and advised the governments of Armenia, Estonia, Yugoslavia, China, Kyrgyzstan, Macedonia, Slovenia and Turkey. In the years 1995-1996 he was State Secretary at the Ministry of Labour, Family and Social Affairs of the Republic of Slovenia. In 1998 he re-employed in the World Bank. In the last year, he is active as professor and researcher at the International School for Social and Business Studies, Slovenia, and Faculty of Management, University of Primorska, Slovenia. 


\section{Managing Academic Leadership via Accountability and Responsibility}

\section{Forum Chair: Dr. Srečko Natek}

International School for Social and Business Studies, Slovenia

Thursday, 21 June $2012 \cdot 13: 30-14: 30$

The role of higher education institutions are changing and in many countries their relation to central government is also evolving. Institutions are becoming more responsible for the development of their own strategies and for the management of their operations. Accountability and responsibility are part of framework. During this Forum, academic leaders will address lessons from managing accountability and responsibility in higher education:

- Building Trust with Stakeholders

- Culture Diversity and Responsibility in the Global Context

- Financing and Budgeting in Higher Education

- Higher Education Governance in a Global Base

- Joint Programs and Degrees

- Lessons from the Corporate World

- Roles and Responsibilities

- Synergy between College and Business Community

- Trust, Markets, and Accountability

- University Governance

- Vision for 2013 and Beyond

\section{Panelists}

Dr. Valerij Dermol, International School for Social and Business Studies, Slovenia

Dr. Alex Koohang, Macon State College, USA

Dr. Andrej Koren, National Leaderships School, Slovenia

Dr. Joseph Mifsud, EMUNI University, Slovenia

Dr. Karim Moustaghfir, Al Akhawayn University in Ifrane, Morocco

Dr. Kongkiti Phusavat, Faculty of Engineering, Kasetsart University, Thailand

Dr. Bordin Rassameethes, Faculty of Business Administration, Kasetsart University, Thailand

Dr. Cezar Scarlat, Universitalea Politehnica Bucuresti, Romania

Dr. Steve Kuang-Hsun Shih, Academic Affairs, Chinese Culture University, Taiwan

Dr. Agnieszka Sitko-Lutek, Faculty of Economics, Maria Currie-Skłodowska University, Poland

Dr. Antonio Uricchio, Faculty of Law and Faculty of Economy, University of Bari, Italy

Dr. Darko Zupanc, National Examinations Centre, Slovenia 


\title{
Insights from Journal Editors
}

\author{
Panel Chair: Dr. Binshan Lin \\ Industrial Management \& Data Systems, www.emeraldinsight.com/imds.htm \\ Louisiana State University in Shreveport, USA
}

Friday, 22 June $2012 \cdot 9: 30-10: 30$

The Editors' Panel aims to bring top editors from leading international journals around the world to share their ideas about selection consideration and criteria for a potential publication. This discussion is expected to benefit and strengthen possible publications among doctoral students as well as junior faculties. The editors' insights and viewpoints are important for a submission preparation.

\section{Panel Members}

Dr. Štefan Bojnec

Management, www.mng.fm-kp.si

Managing Global Transitions, www.mgt.fm-kp.si

University of Primorska, Slovenia

Dr. Gorazd Justinek

International Journal of Diplomacy and Economy, www.inderscience.com/ijdipe International Journal of Globalisation and Small Business, www.inderscience.com/ijgsb International School for Social and Business Studies, Slovenia

Dr. Alex Koohang Interdisciplinary Journal of E-Learning and Learning Objects, http://ijello.org Macon State College, USA

Dr. Andrej Koren and Mateja Brejc, MSc Leadership in Education, http://www.solazaravnatelje.si/zaloznistvo/revija-vodenje/ National School for Leadership in Education, Slovenia

Dr. Dušan Lesjak International Journal of Management in Education, www.inderscience.com/ijmie International School for Social and Business Studies, Slovenia

Dr. Lučka Lorber International Journal of Euro-Mediterranean Studies, www.ijems.emuni.si University of Maribor, Slovenia

Dr. Sasivimol Meeampol International Journal of Accounting Practice and Research, Kasetsart University, Thailand

Dr. Haruthai Numprasertchai International Journal of Business Development and Research, www.bus.ku.ac.th Kasetsart University, Thailand 
Dr. Joanna Paliszkiewicz

Management and Production Engineering Review, www.review.univtech.eu

Warsaw University of Life Sciences, Poland

Dr. Zbigniew Pastuszak

International Journal of Services and Standards, www.inderscience.com/ijss

Maria Curie-Skłodowska University, Poland

Dr. Kongkiti Phusavat

International Journal of Innovation and Learning, www.inderscience.com/ijil

Kasetsart University, Thailand

Dr. Steve Kuang-Hsun Shih

International Journal of Performance Measurement,

http://performancesforum.org/index.html Chinese Culture University, Taiwan

Journal of Accounting, Finance \& Management Strategy,

https://sites.google.com/site/journaljafms/

Chinese Culture University, Taiwan

Dr. Suparerk Sooksmarn

International Journal of Sustainable Strategy and Research

Kasetsart University, Thailand

Dr. Darko Štrajn

Šolsko polje (School Field), www.pei.si//pei_english.aspx

Educational Research Institute

Dr. Nada Trunk Širca

International Journal of Management, Knowledge and Learning, http://www.ijmkl.si

International School for Social and Business Studies, Slovenia

Dr. Agnieszka Sitko-Lutek

International Journal of Synergy and Research, www.ijsr.umcs.lublin.pl

Maria Curie-Skłodowska University, Poland

Dr. Egon Žižmond

International Journal of Sustainable Economy, www.inderscience.com/ijse

University of Primorska, Slovenia 


\section{Entrepreneurship Opportunities in a Globalised World}

\section{Forum Chair: Rado Pezdir}

International School for Social and Business Studies, Slovenia

Friday, 22 June $2012 \cdot 12.00-13.00$

Business Excellence Forum is an opportunity to identify and discuss entrepreneurial and business challenges in a globalizing international environment. Entrepreneurs and businessmen from Europe and elsewhere will highlight practical experiences, good practices and opportunities which they have identified in their activities. The Forum is also an opportunity to reflect on the relevant business and academic responses to existing and future corporate and business challenges.

Speakers who will, in accordance with business practice and their own experience, present their views on the topic of the Forum 'Entrepreneurship Opportunities in a Globalised World,' are:

Mr. Matija Novak, Commercial Director, Steklarna Rogaška d.d., Slovenia

Mr. Anton Škrabl, Construction and Restoration of Pipe Organs and Other Instruments, Slovenia

Dr. Bordin Rassameethes, Kasetsart University, Thailand

Dr. Anna Rakowska, Maria Curie-Skłodowska University, Poland

Dr. Mitja I. Tavčar, International School for Social and Business Studies, Slovenia

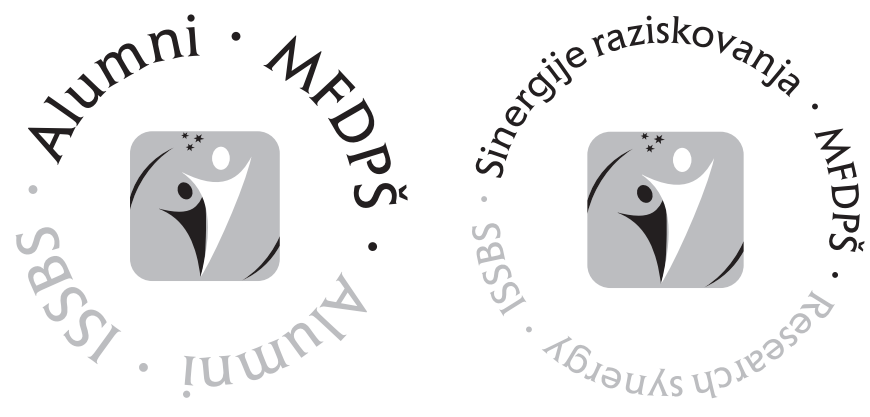

12 


\section{Conference Programme}

\section{Wednesday, 20 June 2012}
16.00-18.00 Pre-Conference Programme • Room A
18.15-19.30 Guided tour around Celje's historical centre to the Water Tower Celje. Meeting point in front of ISSBS building, in front of Hotel Štorman and in front of Hotel Evropa.
19.00-20.00 Registration - The Water Tower Celje (Hotel Evropa)
20.00-21.30 Welcome addresses and welcome reception - The Water Tower Celje ISSBS Dean with all organisers

\section{Thursday, 21 June 2012}

\begin{tabular}{|c|c|}
\hline $8.30-9.00$ & Registration $\cdot 2$ nd floor lobby \\
\hline $9.00-9.30$ & $\begin{array}{l}\text { Conference opening } \cdot \text { Room A } \\
\text { Dr. Srečko Natek, Dean of International School for Social and Business } \\
\text { Studies, Slovenia } \\
\text { Mrs. Darja Turk, Vice Major of Celje } \\
\text { Dr. Valerij Dermol, International School for Social and Business Stud- } \\
\text { ies, Slovenia, Programme Chair } \\
\text { Dr. Binshan Lin, College of Business Administration, Louisiana State } \\
\text { University, USA, Conference Director }\end{array}$ \\
\hline $9.30-10.10$ & $\begin{array}{l}\text { Keynote speaker } 1 \cdot \text { Room A } \\
\text { Mr. Maciej Maniecki } \\
\text { Discussion }\end{array}$ \\
\hline $10.30-10.15$ & Photo session \\
\hline 10.15-10.45 & Coffee break • 2nd floor lobby \\
\hline $10.45-12.00$ & Concurrent sessions A1, B2, B5, C3, C6, E1, G1 \\
\hline $12.00-13.30$ & Lunch $\cdot$ Hotel Štorman \\
\hline $13.30-14.30$ & Academic Leadership Forum $\cdot$ Room A \\
\hline $14.30-15.00$ & Coffee break $\cdot$ 2nd floor lobby \\
\hline $15.00-16.15$ & Concurrent sessions $\mathrm{A} 2, \mathrm{~B} 3, \mathrm{C} 1, \mathrm{C} 4, \mathrm{D} 1, \mathrm{~F} 1, \mathrm{G} 2$ \\
\hline $16.15-16.30$ & Break \\
\hline $16.30-17.45$ & Concurrent sessions B1, B4, C2, C5, D2, F2, H1 \\
\hline 18.30 & $\begin{array}{l}\text { Bus tour to Celje's Old Castle and Dobrna; meeting point in front of } \\
\text { ISSBS building and in front of hotel Evropa }\end{array}$ \\
\hline $20.30-23.00$ & Dinner and social event $\cdot$ Hotel Vita Dobrna \\
\hline
\end{tabular}

Friday, 22 June 2012

9.00-9.30 Demonstration: Tailor Made Texts for Study Purposes • Room G Ms. Erzsebet Csibi, Pearson 


\begin{tabular}{|c|c|}
\hline $9.30-10.30$ & Editors' Panel • Room G \\
\hline $10.30-11.00$ & $\begin{array}{l}\text { Coffee break with Exhibition of Journals, networking for publishing } \\
\text { opportunities } \cdot 2 \text { nd floor lobby }\end{array}$ \\
\hline $11.00-11.30$ & $\begin{array}{l}\text { Keynote speaker } 2 \cdot \text { Room G } \\
\text { Dr. Milan Vodopivec } \\
\text { Discussion }\end{array}$ \\
\hline $11.30-12.00$ & Break for networking and bilateral meetings $\cdot 2$ nd floor lobby \\
\hline $12.00-13.00$ & Business Excellence Forum $•$ Room $G$ \\
\hline 13.00 & Closing of the conference $\cdot$ Room $G$ \\
\hline $13.00-14.00$ & $\begin{array}{l}\text { Programme Board meeting (working lunch for invited guests only) } \\
\text { English Room in Hotel Štorman }\end{array}$ \\
\hline
\end{tabular}

Sessions Timetable - Thursday, 21 June 2012

\begin{tabular}{|c|c|c|c|c|c|c|c|}
\hline & $\begin{array}{l}\infty \\
\varepsilon \\
\delta \\
\varnothing\end{array}$ & 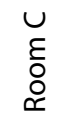 & 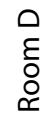 & $\begin{array}{l}\text { س } \\
\varepsilon \\
\varnothing \\
\varnothing\end{array}$ & 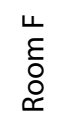 & 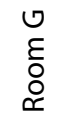 & $\begin{array}{l}\varangle \\
\varepsilon \\
\text { ઠ } \\
\propto\end{array}$ \\
\hline $10.45-12.00$ & A1 & B2 & B5 & $\mathrm{C} 3$ & $\mathrm{C} 6$ & E1 & G1 \\
\hline $15.00-16.15$ & $\mathrm{~A} 2$ & B3 & $\mathrm{C} 1$ & $\mathrm{C} 4$ & D1 & F1 & G2 \\
\hline 16.30-17.45 & B1 & B4 & $\mathrm{C} 2$ & C5 & D2 & F2 & $\mathrm{H} 1$ \\
\hline
\end{tabular}

The distribution of papers by session is of informative nature and is subject to change. The final information will be available on-site.

\section{Sessions}

- Knowledge Management (A1, A2)

- Management, Strategic Management, Organisational Behaviour (B1, B2, B3, B4, B5)

- Learning, Education, Training (C1, C2, C3, C4, C5, C6)

- Human Resources (D1, D2)

- Business, Marketing and Competitiveness (E1)

- Innovation, Entrepreneurship (F1, F2)

- Technology, Informatics, Methodology (G1, G2)

- Knowledge Management Practices (H1)

\section{Post-Conference Programme}

- PhD Students' Workshop 2012 - Academic Writing for Publishing Scientific Papers in International Journals, 22-23 June 2012

- Summer School 2012, 25 June-6 July 2012 - Innovation in Business: Environmental Challenges 


\section{A1 Knowledge Management 1}

Thursday, 21 June $2012 \cdot 10.45-12.00 \cdot$ Room B

Session Chair: Peter Meža

Product Management and Knowledge Management

Peter Meža, International School for Social and Business Studies, Slovenia

Keywords: knowledge management, product management, knowledge,

information, strategy

Full Text

Knowledge Management in the Innovation Potential of Enterprises

Tomasz Norek, University of Szczecin, Poland

Keywords: knowledge management, innovation potential, benchmarking

Full Text

Possibilities of Knowledge Management in Supporting Marketing Activities of Firms

Veronika Svatošová, University of Pardubice, Faculty of Economics and Administration, Czech Republic

Keywords: knowledge management, knowledge and information, marketing, new trends of marketing, knowledge marketing

Full Text

Relationship between Knowledge Management and Market Orientation in SMEs Roman Kmieciak, Silesian University of Technology, Poland

Anna Michna, Silesian University of Technology, Poland

Keywords: knowledge management, market orientation, SMEs

Full Text

Integration of Academic Libraries' E-Services into Learning Management System: Students' Perception

Anita Papić, Faculty of Philosophy, University J. J. Strossmayer, Croatia

Ivanka Stričević, University of Zadar, Croatia

Keywords: learning management system, teachers, students, academic libraries, information literacy

Full Text

The Importance of Concepts of Knowledge Management and Learning Organization in Managing the Knowledge-Flow in Organizations

Marija Dzunić, Jelena Djordjević Boljanović, and Jana Subotić,

Faculty of Economics, Finance and Administration, University Singidunum, Serbia

Keywords: knowledge economy, knowledge-flow, knowledge management, learning organization, competitive advantage

Full Text 


\section{A2 Knowledge management 2}

Thursday, 21 June $2012 \cdot 15.00-16.15 \cdot$ Room B

Session Chair: Stanislav Tripes

Leveraging Knowledge for Improved Sport Club Performance Management Stanislav Tripes, Faculty of Management, University of Economics, Czech Republic Jan Voracek, Faculty of Management, University of Economics, Czech Republic Keywords: sport club, performance management, knowledge conceptualization, dynamic modelling

Full Text

\section{Commitment Enhances Knowledge Sharing against Opportunism in New} Product Development

Richard C.M. Yam, City University of Hong Kong, Hong Kong

Esther P.Y. Tang, Hong Kong Polytechnic University, Hong Kong

Cliff C.H. Chan, City University of Hong Kong, Hong Kong

Keywords: knowledge sharing, opportunism, contract, commitment, trust

Full Text

Japanese Way, Western Way: Two Narratives of Knowledge Management Robert Joseph Skovira, Robert Morris University, USA

Keywords: tacit knowledge, explicit knowledge, personal knowing, organizational knowing, Japanese narrative, Western narrative

Full Text

Product Package Second Life: Exploratory Research of Secondary Use

Monika Nalewajek, Maria Curie-Skłodowska University, Poland

Radosław Mącik, Maria Curie-Skłodowska University, Poland

Keywords: package, product second-life, photostory, self-reports

Full Text

\section{Measurement of Intellectual Capital in a Company}

Artur Paździor, College of Enterprise and Administration, Poland

Maria Paździor, College of Enterprise and Administration, Poland

Keywords: intellectual capital, synthetic methods, analytical methods

Full Text

Managing Knowledge and Information in the Process of Customer Needs Identification

Elżbieta Skrzypek, Maria Curie-Skłodowska University, Poland

Grzegorz Grela, Maria Curie-Skłodowska University, Poland

Agnieszka Piasecka, Maria Curie-Skłodowska University, Poland

Mariusz Hofman, Maria Curie-Skłodowska University, Poland

Keywords: customer focus, knowledge and information, ISO 10014

Full Text

16 


\title{
B1 Management, Strategic Management, Organisational Behaviour 1
}

Thursday, 21 June $2012 \cdot 16.30-17.45 \cdot$ Room B Session Chair: Gyula Fülöp

Corporate Sustainability: Strategic Alternatives and Methodology; Implementation

Gyula Fülöp, Institute of Business Sciences, University of Miskolc, Hungary Bettina Hódi Hernádi, Institute of Business Sciences, University of Miskolc, Hungary Keywords: sustainability, corporate strategy, balanced scorecard Full Text

Quality as a Strategy for the Development of Competitive Advantages in the health Institutions for Achieving Business Success

Veselin Dickov, Faculty of International Management, European University, Serbia Keywords: strategic analysis, economic indicators, balanced scorecard, the financial indicators, pharmaceutical marketing strategies

Full Text

\author{
Global Supply Chain Compliance Issues: A Cultural Perspective \\ Linda C. Gordon, University of La Verne, USA \\ David S. Kung, University of La Verne, USA \\ Nancy R. Tao, University of Wisconsin, USA \\ Harold Dyck, California State University, USA \\ Keywords: globalization, supply chain management, cultural management \\ Full Text
}

\section{Orientation on Trust and Organizational Performance}

Joanna Paliszkiewicz, Warsaw University of Life Sciences, Poland

Keywords: trust, trust management, organizational performance

Full Text

The Challenges of Globalization: The Changing Role of Cultural Intelligence in the 21 st Century

Réka Polák-Weldon, University of Pannonia, Hungary

Ágnes Balogh, University of Pannonia, Hungary

Eszter Bogdány, University of Pannonia, Hungary

Tibor Cizmadia, University of Pannonia, Hungary

Keywords: changing role of cultural intelligence, globalization, success attitude Full Text 


\title{
B2 Management, Strategic Management, Organisational Behaviour 2
}

\author{
Thursday, 21 June $2012 \cdot 10.45-12.00 \cdot$ Room C \\ Session Chair: Anna Rakowska \\ Instances of Corporate Social Responsibility in Coal Mining: \\ An Example of Chosen Polish Mines \\ Anna Rakowska, Marie Curie-Skłodowska University, Poland \\ Marzena Cichorzewska, Lublin University of Technology, Poland \\ Keywords: CSR, safety, wellbeing, culture, environment \\ Full Text
}

Future Employee Preferences in the Light Of Organizational Culture

Eszter Bogdány, University of Pannonia, Hungary

Ágnes Balogh, University of Pannonia, Hungary

Tibor Csizmadia, University of Pannonia, Hungary

Réka Polák-Weldon, University of Pannonia, Hungary

Keywords: change management, organizational culture, changing preferences

Full Text

Making Knowledge Strategies Based on Organizational Life Cycle:

A Case Study in Automobile Industry

Mohammad Reza Ostad Ali Naghi Kashani, Islamic Azad University (IAU),

Tehran Central Branch (TCB), Iran

Keywords: knowledge management, knowledge strategies, organization lifecycle

Full Text

Adaptation to Climate Change As a Process of Organizational Learning Agnieszka Leszczynska, Maria Curie-Skłodowska University, Poland Keywords: climate change, adaptation, organizational learning Full Text

Corporate Social Responsibility and its Application in the Enterprise Bartłomiej Zinczuk, University of Maria Curie-Skłodowska, Poland

Keywords: CSR, relationship, environment

Full Text 


\section{B3 Management, Strategic Management, Organisational Behaviour 3}

Thursday, 21 June $2012 \cdot 15.00-16.15 \cdot$ Room C

Session Chair: Mitja Gorenak

The Importance of Organizational Values for Organization

Mitja Gorenak, International School for Social and Business Studies, Slovenia

Suzana Košir, International School for Social and Business Studies, Slovenia

Keywords: indicate organizational values, organization, explicit or implicit notes of values, performance

Full Text

\section{Enterprise Flight Envelope: Conceptual Dynamic Framework for Crisis Management}

Veronika Zelena, Faculty of Management, University of Economics, Czech Republic Jan Voracek, Faculty of Management, University of Economics, Czech Republic Keywords: crisis management, performance measure, flight management simulators, redesign, reengineering

Full Text

\section{Shaping Alumni's Sensitivity to Issues of Social Logistics}

Sebastian Twaróg, University of Economics in Katowice, Poland Jacek Szołtysek, University of Economics in Katowice, Poland Rafał Otręba, Complex of John Paul II Comprehensive Schools No. 3 in Ruda Slaska, Poland

Keywords: logistics, social logistics, social sensitivity Full Text

3Rs Absorptive Capacity: Responsive, Realized, and Reconfigured Yuh-Yuan Tsai, National Dong Hwa University, Taiwan Chien-Nan Chen, National Dong Hwa University, Taiwan Chin-Li Tseng, National Dong Hwa University, Taiwan Keywords: absorptive capacity, organizational innovation, reconceptualization Full Text

Intercultural Communication: The Effect of Cultural Differences in Everyday Working Environment of Companies (from Germany, Switzerland, Austria) in Hungary

Krisztina Frankó, University of Debrecen, Faculty of Economics and Business Administration, Hungary

Keywords: intercultural management, cultural differences, intercultural interaction, compromise, leadership, Hungary, Germany, Austria, Switzerland

Full Text 


\section{B4 Management, Strategic Management, Organisational Behaviour 4}

Thursday, 21 June $2012 \cdot 16.30-17.45 \cdot$ Room C

Session Chair: Valerij Dermol

Relationship between Mission Statement and Company Performance Valerij Dermol, International School for Social and Business Studies, Slovenia Keywords: company mission, mission statement, company performance Full Text

Strategic Management of air Transport Resources in Fuel Crisis Conditions Katarzyna Wąsowska, Siedlce University of Natural Sciences and Humanties, Poland Keywords: air transport, fuel crisis

\section{Full Text}

The New Mechanism for Performance Evaluation of the Co-Operatives Chamaru De Alwis, Faculty of Management and Economics, Tomas Bata University, Czech Republic

Keywords: co-operatives, values, principles, financial performance, value performances

Full Text

Private Equity Opportunities in the Countries of Central and Eastern Europe Darina Saxunova, Comenius University, Slovakia Keywords: private equity, mergers and acquisitions, PE funds, CEE region Full Text

Feasibility of Cotton Cultivation in Thailand Punnamee Sachakamol, Kasetsart University, Thailand Keywords: cotton, feasibility study, forecasting, simulation, commodity trading Full Text 


\section{B5 Management, Strategic Management, Organisational Behaviour 5}

Thursday, 21 June $2012 \cdot 10.45-12.00 \cdot$ Room D

Session Chair: Sasivimol Meeampol

An Empirical Analysis of the Relation between Corporate Governance and Earnings Management: Case Study of Thailand

Sasivimol Meeampol, Kasetsart University, Thailand

Sarayut Rueangsuwan, Kasetsart University, Thailand

Pairin Jaithat, Kasetsart University, Thailand

Keywords: corporate governance, earnings management, discretionary accruals Full Text

Coopetition in the Context of Assumptions of the Resource Based View Piotr Markiewicz, Cracow University of Economics, Poland

Keywords: strategy, coopetition, learning, creation of value

Full Text

Ranking and Visualizing the Keywords in Mission Statements of Slovenian Companies

Kristijan Breznik, International School for Social and Business Studies, Slovenia

Keywords: mission statement, social network analysis, ranking, visualization

Full Text

Effectiveness of Communication in Relation to Training of Sales Staff

Gregor Jagodič, International School for Social and Business Studies, Slovenia

Keywords: training, communication, business performance

Full Text

Implementing JIT Philosophy in Push Based Production System

Jiravut Wattananusornand, Faculty of Engineering, Kasetsart University, Thailand Pornthep Anussornnitisarn, Faculty of Engineering, Kasetsart University, Thailand Bordin Rassameethes, Faculty of Business Administration, Kasetsart University, Thailand

Keywords: CONWIP, JIT control mechanism, constant work-in-process

Full Text

Root Cause Analysis Using Internal Benchmarking

Maleewan Sapcharoenkul, Faculty of Engineering, Kasetsart University, Thailand Pornthep Anussornnitisarn, Faculty of Engineering, Kasetsart University, Thailand Suparerk Sooksmarn, Faculty of Business Administration, Kasetsart University, Thailand

Keywords: internal benchmarking, Little's law, constant work-in-process

Full Text 


\section{C1 Learning, Education, Training 1}

Thursday, 21 June $2012 \cdot 15.00-16.15 \cdot$ Room D

Session Chair: Sonja Pravilović

Influence of the Cooperation with Professional Consultants

on the Improvement in the Effectiveness of the Enterpises

Urszula Skurzynska-Sikora, Maria Curie-Sklodowska University, Poland

Keywords: competence gap, reducing competence gap, enterprise's effectiveness

Full Text

Team Re-Shuffle (Three Years Study)

Václav Švec, Czech University of Life Sciences Prague, Czech Republic Ivana Tichá, Czech University of Life Sciences Prague, Czech Republic

Tereza Kaderábková, Czech University of Life Sciences Prague, Czech Republic

Keywords: team learning, management, team, compentencies

Full Text

Relative Efficiency of Secondary Education: A Comparative Analysis of Slovenia and Croatia

Aleksander Aristovnik, University of Ljubljana, Slovenia

Keywords: secondary education, technical efficiency, DEA, Slovenia,

Croatia, EU, OECD

Full Text

Why Learning by Exporting May Not Be As Common As You Think

Tomasz Serwach, University of Lodz, Poland

Keywords: learning by exporting, trade and heterogeneous firms

Full Text

\section{A Study on Taiwanese University Student'S Personality Traits} and Motivations of Overseas Internship

Jin-Jun Fan, National Pingtung Institute of Commerce, Taiwan, ROC

Hsiang-Yung Feng, National United University, Taiwan, ROC

Keywords: overseas internship, personality traits, motivations,

confirmatory factor analysis

Full Text 


\section{C2 Learning, Education, Training 2}

Thursday, 21 June $2012 \cdot 16.30-17.45 \cdot$ Room D

Session Chair: Vaska Pejić

\section{Comparison between Logistics Experts in Commercial} and Transport Companies

Vaska Pejić, University of Maribor, Faculty of Logistics, Slovenia Irena Gorenak, University of Maribor, Faculty of Logistics, Slovenia Sonja Mlaker Kač, University of Maribor, Faculty of Logistics, Slovenia Keywords: competencies, logistics expert, commercial companies, transport companies

Full Text

Internationalization through Web Based Learning? An Assessment of the Virtualization of German Universities

Marc Cuypers, University of Duisburg-Essen, Germany

Keywords: internationalization, virtualization, rationales

Full Text

\section{Challenges and Responses: Learning in Nonprofit Organizations}

Katalin Dobrai, University of Pécs, Hungary

Ferenc Farkas, University of Pécs, Hungary

Keywords: non-profit organizations, professionalization, learning, managerialism, organizational development

Full Text

Collaborative Process Learning on the Shop-Floor from the Perspectives of Lean Management

Milan Fekete, Comenius University in Bratislava, Slovak Republic

Zuzana Miklošíková, Comenius University in Bratislava, Slovak Republic

Keywords: collaborative learning, process learning, lean management, knowledge management, acquiring and sharing the knowledge

Full Text

The Development of Expertise in Education and Training Management

Julia Breßler, Chemnitz University of Technology, Germany

Keywords: expertise, innovation, education and training management, educational goal

Full Text 


\section{C3 Learning, Education, Training 3}

Thursday, 21 June $2012 \cdot 10.45-12.00 \cdot$ Room E

Session Chair: Sabina Đonlagić

Determining Key Factors for Knowledge Economy Development in Bosnia and Hercegovina

Adil Kurtić, Faculty of Economics, University in Tuzla, Bosnia and Herzegovina Sabina Đonlagić, Faculty of Economics, University in Tuzla, Bosnia and Herzegovina Keywords: knowledge economy, knowledge economy factors, higher education in knowledge economy

Full Text

The Use of Modern Technologies in Higher Schools As One of the Elements of Value Innovation

Bogdan Nogalski, Gdańsk University, Poland

Marzena Wójcik-Augustyniak, Siedlce University of Natural Sciences and Humanities,

Poland

Keywords: modern technologies, higher schools, value innovation

Full Text

Entrepreneurship Education, Democratic Empowerment and Subjective Well-Being

Zsuzsanna Horváth, College of Commerce, Catering and Tourism, Budapest Business School, Hungary

Keywords: tourism education, democratic deficit, entrepreneurship education, empowerment, subjective well-being

Full Text

Assessing the Emotional Intelligence of Sri Lankan High School Students: A Case Study

L.N.A. Chandana Jayawardena, Faculty of Management and Economics, Tomas Bata University in Zlin, Czech Republic and University of Peradeniya, Sri Lanka

L.N.A. Ishanthi Jayawardena, Sacred Heart Convent, Sri Lanka

Keywords: emotional intelligence, high school students, adolescence

Full Text

Role of Inter-Organizational Relations in Obtaining Sponsorhip for Academic Initiatives

Wioletta Wereda, Faculty of Management, Siedlce University of Natural Sciences and Humanities, Poland

Keywords: inter-organizational relations, sponsorship, academic initiatives, coopetition

Full Text

24 


\section{C4 Learning, Education, Training 4}

Thursday, 21 June $2012 \cdot 15.00-16.15 \cdot$ Room E Session Chair: Natascha Zeitel-Bank

'Networked Learning' at the Management Center Innsbruck, Austria Natascha Zeitel-Bank, Management Center Innsbruck, Austria Ute Tat, Management Center Innsbruck, Austria

Keywords: networked learning, experiential learning, integrated learning Full Text

Strategy of the Field of Study Choice: Research Among Male Students/Future Graduates in the Vysocina Region; Focus on Nursing Martina Chalupova, College of Polytechnics Jihlava, Czech Republic Keywords: senior male students, field of study choice factors, nursing, Vysocina region

Full Text

\section{Reaching Maturity through Project-Based Learning}

Seweryn Spalek, Silesian University of Technology, Faculty of Organisation and Management, Poland

Keywords: project-based learning, maturity, educational organisations, practical knowledge, industrial companies' expectations

Full Text

Whose Interest Serves the Internationalisation of Higher Education? Tanja Potočnik Mesarić, University of Ljubljana, Slovenia

Keywords: internationalisation, higher education, Bologna process, motives Full Text

The Role of Mentoring in Organisational Learning: Case Study on the University Martyna Wronka, University of Economics in Katowice, Poland Keywords: mentoring, university, mentee, mentor, learning organisation Full Text 


\section{C5 Learning, Education, Training 5}

Thursday, 21 June $2012 \cdot 16.30-17.45 \cdot$ Room E

Session Chair: Nina Harapin

Expects of Informing Students about Future Study

Nina Harapin, Gimnazija Brežice, Slovenia

Suzana Košir, International School for Social and Business Studies, Slovenia

Keywords: education, cooperation, secondary school, higher education, faculty

Full Text

Business Process Management Training and Certification Program:

A Slovenian-Romanian Collaboration Experience

Anca Draghici, Politehnica Unviersity of Timisoara, Romania

Cristian Olariu, Politehnica Unviersity of Timisoara, Romania

Tomislav Rozman, Bicero d.o.o., Slovenia

Keywords: business process management, skill set, qualification, training program, certification, European Certification and Qualification Association

Full Text

The Experience of Setting up a New Learning Environment Model in Management Education: Challenges and Frustrations

Jorge Santos, Federal University of Viçosa, MG, Brazil

Simone Martins, Federal University of Viçosa, MG, Brazil

Keywords: experiential learning, learning environments, management education

Full Text

On the Need of Humanistic Preparatory Courses at Business and Technical Schools

Dominika Boroń, Maria Curie-Skłodowska University, Poland

Keywords: humanistic education, culture, social responsibility, communication crisis, humanistic management

Full Text

Experience of Erasmus Students Studying in Poland

Marcin Lipowski, Maria Curie-Skłodowska University, Poland

Keywords: student mobility, Erasmus students, study abroad, student needs

Full Text 


\section{C6 Learning, Education, Training 6}

Thursday, 21 June $2012 \cdot 10.45-12.00 \cdot$ Room F

Session Chair: Vesna Skrbinjek

\section{Enrolment Trends in Full-Time Undergraduate Tertiary Education Studies in Slovenia}

Vesna Skrbinjek, International School for Social and Business Studies, Slovenia Dušan Lesjak, International School for Social and Business Studies, Slovenia

Keywords: tertiary education, Slovenia, enrolment, enrolment trends, full-time studies

Full Text

\section{Competences of University Graduates from Economics and Management,} as Perceived by University Students and Employers

Agnieszka Sitko-Lutek, Maria Curie-Skłodowska University, Poland

Monika Jakubiak, Maria Curie-Skłodowska University, Poland

Keywords: competences, economics and management students, significance of competences at work, the level of competences gained during studies

Full Text

Quality Evaluation of Higher Education Programmes:

Process and Challenges in Latvia

leva Brence, Latvian Academy of Sciences, Latvia

Baiba Rivza, Latvian Academy of Sciences, Latvia

Keywords: higher education programmes, evaluation, quality of higher education

Full Text

\section{Internationalization of Higher Education: A Case Study of Leonardo da Vinci Project}

Elżbieta Miłosz, College of Business and Administration in Lublin, Poland Marek Miłosz, Lublin University of Technology, Poland Jean-Michel Adam, Pierre Mendes France University, France and Laboratory of Informatics of Grenoble (LIG), France

Sergio Lujan Mora, University of Alicante, Spain

Nada Trunk Širca, International School for Social and Business Studies, Slovenia

Keywords: higher education, internationalization, knowledge exchange,

multicultural environment

Full Text

\section{Research into Hofstede's Thesis}

Frederick G. Kohun, Robert Morris University, USA

Vladimir Burčik, Comenius University, Slovakia

Robert Joseph Skovira, Robert Morris University, USA

Keywords: Hofstede, knowledge management tool, global socio-economic change Full Text 


\section{D1 Human Resources 1}

Thursday, 21 June $2012 \cdot 15.00-16.15$ • Room F

Session Chair: Karim Moustaghfir

Predicting Employees' Behavior: An Application of the Theory of Planned Behavior; The Case of the Moroccan Forestry Department (HCEFLCD)

Redouan Innan, Haut Commissariat aux Eaux et Forêts et á la Lutte Contre

la Désertification, Morocco

Karim Moustaghfir, Al Akhawayn University in Ifrane, Morocco

Keywords: theory of planned behaviour, complementary healthcare insurance, attitude, subjective norm, perceived behavioural control

Full Text

\section{Chances of Men and Women to Return to the Labour Market} after Child-Care Leave

Andrea Bencsik, Széchenyi István Egyetem, Hungary

Juhász Tímea, LAH Hungaria Kereskedelmi Kft., Hungary

Keywords: reconciliation of work and private life, child-care leave, return to the labour market

Full Text

\section{Assessment Survey on Management Abilities and Knowledge of Managers of SMEs}

Gábor Zsakay, University of Pécs, Faculty of Business and Economics, Hungary Keywords: measurement of management skills, assumed knowledge, real knowledge, SMEs

\section{Full Text}

\section{Empowerment in High Performance Work Systems from a Systems Theory} Perspective

Thomas Wallner, University of Applied Sciences Upper Austria, Austria Martin Menrad, University of Applied Sciences Upper Austria, Austria Stefan Thurner, University of Applied Sciences Upper Austria, Austria Keywords: high performance work systems, high performance work practices, systems theory, complex adaptive systems, empowerment

\section{Full Text}

\section{Youth Unemployment: Should We Detect Talents and Develop} Career Paths Earlier?

Ivana Čančar, Institute for Developmental and Strategic Analysis, Slovenia Darka Podmenik, Institute for Developmental and Strategic Analysis, Slovenia Keywords: youth unemployment, talents, career, early career paths Full Text 


\section{D2 Human Resources 2}

Thursday, 21 June $2012 \cdot 16.30-17.45 \cdot$ Room F

Session Chair: Vilma Alina Šoba

Some Legislative and Social Obstacles in Career of Slovene Women in Science Vilma Alina Šoba, International School for Social and Business Studies, Slovenia Jana Goriup, Faculty of Arts, University of Maribor, Slovenia

Keywords: women, science, education, domestic work, family, balance, discrimination, inequality, Slovene society

Full Text

\section{Conflicts and Cooperation in the Shifting Social Environment: The Case of Lithuania Juozas Lakis, Bialystok University of Technology, Poland}

Keywords: transformations, Lithuania, conflict management, alternative dispute resolution (ADR)

Full Text

Relationships between Organization of R\&D Department and Innovativeness of a Company: Recommendations for HRM

Tomasz Ingram, University of Economics in Katowice, Poland

Keywords: organizational innovativeness, human resource management

Full Text

The Employee Appraisal Method Based on the Agreement on Objectives

Christian Seitz, Slovak University of Agriculture, Slovak Republic

Keywords: employee appraisal, objective agreement, management by objectives, objective theory

Full Text

Workforce Localization Policies in Saudi Arabia: The Determinants of Successful Implementation in Multi-National Enterprises

Abdullah Alanezi, Brunel University London, Great Britain

Keywords: localization policies, Saudization, institutional theory, HR practices, role of HR director

Full Text

The Relationship between Human Resource Development System and Job Satisfaction

Nada Trunk Širca, International School for Social and Business Studies, Slovenia Katarina Babnik, University of Primorska, Faculty of Health Sciences, Slovenia Kristijan Breznik, International School for Social and Business Studies, Slovenia Keywords: job satisfaction, HR development system, HR function, social exchange theory, psychological climate

Full Text 


\section{E1 Business, Marketing and Competitiveness}

Thursday, 21 June $2012 \cdot 10.45-12.00 \cdot$ Room G

Session Chair: Štefan Bojnec

Launching of a New Product with the Brand Extension Strategy

Tina Vukasovič, International school for social and business studies, Slovenia

Keywords: brand extension, food industry, marketing

Full Text

Price Regulation for Medicinal Products in Slovenia

Štefan Bojnec, University of Primorska, Faculty of Management, Slovenia

Romana Kajdiž, Agency for Medicinal Products and Medical Devices of the Republic

of Slovenia, Slovenia

Keywords: prices for medicinal products, reference price system, public expenditures for medicinal products

Full Text

Continuing Education Services: Perceived Service Value and Related Constructs Otto Krickl, University of Graz, Austria

Susan Geertshuis, University of Auckland, New Zealand

Keywords: continuing education, perceived service value, community education, willingness to pay

Full Text

Implementation of the Process Approach and Business Process Management Concept in Croatian Shipyards

Ivana Mikačić, University of Split, Faculty of Economics, Croatia

Željana Dulčić, University of Zagreb, Faculty of Philosophy, Croatia

Keywords: global market, competition, process approach, business process

management, Croatian shipyards

Full Text

Knowledge as the Power of New Consumers in the Global Environment

Ružica Kovač Žnideršić, Aleksandar Grubor, Suzana Salai, and Dražen Marić, Faculty of Economics Subotica, University of Novi Sad, Serbia

Keywords: new consumers, values, new time, knowledge, learning

Full Text

E-Marketing Activities and Perceived Competitive Advantage in the Context of Globalization: Study of Lublin Region Firms Radosław Mącik, Maria Curie-Skłodowska University, Poland Bartosz Jóźwik, The John Paul II Catholic University of Lublin, Poland Monika Nalewajek, Maria Curie-Skłodowska University, Poland Keywords: globalization, e-marketing, competitive advantage, SMEs Full Text

30 


\section{F1 Innovation, Entrepreneurship 1}

Thursday, 21 June 2012 • 15.00-16.15 • Room G Session Chair: Gorazd Justinek

Global Economic and Financial Crisis: A Threat for Innovative SMEs

Tanja Sedej, International School for Social and Business Studies, Slovenia Gorazd Justinek, International School for Social and Business Studies, Slovenia Keywords: global crisis, innovation, SMEs

Full Text

Learning from the Palomar5 Innovation Camp: Towards a Framework for a New User Innovation Methodology

Aiko Karaschewitz, Technische Universität Berlin, Germany Katharina Hölzle, Universität Potsdam, Germany

Keywords: Palomar5, knowledge management, innovation camp framework Full Text

\section{School and Development of Innovation}

Franc Cankar, National Education Institute, Slovenia

Stanka Setnikar Cankar, University of Ljubljana, Faculty of Administation, Slovenia Keywords: school, teachers, innovation

Full Text

Innovation and Export Performance: Evidence from Lublin Voivodeship Aneta Karasek, Maria Curie-Skłodowska University, Poland

Keywords: innovation, export, SMEs

Full Text 


\section{F2 Innovation, Entrepreneurship 2}

Thursday, 21 June $2012 \cdot 16.30-17.45 \cdot$ Room G

Session Chair: Tudorel Popescu

Entrepreneurial vs. Administrative Management in Not-for-Profit

Organizations - Public Administration and Universities

Cezar Scarlat, University 'Politehnica' of Bucharest, Romania

Bogdan Brustureanu, National Council for Higher Education Funding (CNFIS),

Romania

Daniela Borangic, University 'Politehnica' of Bucharest, Romania

Tudorel Popescu, University 'Politehnica' of Bucharest, Romania

Keywords: entrepreneurial management, administrative management,

balanced-management, entrepreneurial university, entrepreneurial public

administration

Full Text

Globalization as a Source of Innovation in Hard Coal Mining Izabela Jonek-Kowalska, Silesian University of Technology, Poland

Keywords: mining enterprises, innovation, globalization

Full Text

The Relationship of the Spin-off Process and the Higher Education in Hungary Krisztina Németh, Budapest Business School, College of Finance and Accountancy, Hungary, and Széchenyi István University, Doctoral School of Regional and Economic Sciences, Hungary

Szilárd Németh, Széchenyi István University, Hungary

Keywords: career goals, higher education environment, entrepreneurial courses

Full Text

Creativity Online: Violation of Copyright and Protection of Copyleft

Augusto Sebastio, University of Bari, Italy

Keywords: creativity, innovation, learning capability, copyright and copyleft

Full Text 


\section{G1 Technology, Informatics, Methodology 1}

Thursday, 21 June $2012 \cdot 10.45-12.00 \cdot$ Room A Session Chair: Yasemin Bal

The Importance of Using Human Resources Information Systems (HRIS) and a Research on Determining the Success of HRIS

Yasemin Bal, Yıldız Technical University, Turkey

Serdar Bozkurt, Yıldız Technical University, Turkey

Esin Ertemsir, Yıldız Technical University, Turkey

Keywords: management information systems, human resources information systems Full Text

\section{Error Correction Model for the Service Company}

Aleksander Janeš, University of Primorska, Faculty of Management, Slovenia Keywords: microeconomic level, error correction model, cointegration, error correction term, KPIs

Full Text

Information Asymmetry in the Artificial Financial Market Represented by Scale-Free Network

Ognjen Radović, Faculty of Economics, University of Niš, Serbia Jelena Stanković, Faculty of Economics, University of Niš, Serbia

Keywords: information asymmetry, artificial financial market, scale-free network Full Text

Effectiveness of Information Systems Implementation: The Case of the Polish Small and Medium Enterprises Łukasz Wiechetek, Maria Curie-Skłodowska University, Poland Keywords: ICT effectivness, ICT implementation, SME, implementation perception Full Text

Active Learning in Online Courses: An Examination of Students' Learning Experience

Alex Koohang, Macon State College, USA

Keywords: e-learning, active learning, online education, learning experience Full Text 


\section{G2 Technology, Informatics, Methodology 2}

Thursday, 21 June $2012 \cdot 15.00-16.15 \cdot$ Room A

Session Chair: Marek Miłosz

Individual and Multi-User Digital Identities of Employees in Polish Enterprises: Survey Results

Marek Miłosz, Lublin University of Technology, Poland

Marta Juszczyk, Lublin University of Technology, Poland

Keywords: information security, digital identity, human factors

Full Text

\section{Educational Approach to Accounting Informational System} and Business Organizations

Božidar Jager, Slovenia

Keywords: accounting code, accounting principles, accounting standards, expert auditor

Full Text

\section{Quantitative Model for Information Security Risk Management}

Rok Bojanc, ZZI d.o.o., Slovenia

Keywords: information technology management, modelling security technology, risk management

Full Text

Pros and Cons of International Collaboration: A Case of Serbia and the United States

Alex Koohang, Macon State College, USA

Keywords: international collaboration, higher education institutions, Serbia, United States

Full Text

\section{Comparative Educational Empowerment and Performance} of Racial Groups in American Schools

Olajide O. Agunloye, Augusta State University, USA

Keywords: educational empowerment, performance, policy

Full Text 


\section{H1 Knowledge Management Practices 1}

Thursday, 21 June $2012 \cdot 16.30-17.45 \cdot$ Room A

Session Chair: Svetlana Lazović

The Role and Importance of Emotional Intelligence in Knowledge Management Svetlana Lazović, International School for Social and Business Studies, Slovenia Keywords: knowledge, emotional intelligence, leadership, human resources Full Text

\section{Training in a Company by Means of Knowledge Management}

Leon Lešnik, International School for Social and Bussines Studies, Slovenia Urška Grabar, International School for Social and Bussines Studies, Slovenia Marjeta Rukav, International School for Social and Bussines Studies, Slovenia Franci Toplišek, International School for Social and Bussines Studies, Slovenia Dragica Plivac Kolar, International School for Social and Bussines Studies, Slovenia Matjaž Kovač, International School for Social and Bussines Studies, Slovenia Keywords: management of knowledge, training, systematic and analytical model, questionnaire inquiry, deductive research method, project proposition, reflexive model of training

Full Text

\section{Online Marketing and Networking of Company}

Aleksander Hren, International School for Social and Business Studies, Slovenia Saša Hren, International School for Social and Business Studies, Slovenia Saša Mohor, International School for Social and Business Studies, Slovenia Aljoša Gačnik, International School for Social and Business Studies, Slovenia Andrej Čuček, International School for Social and Business Studies, Slovenia Denis Padjan, International School for Social and Business Studies, Slovenia Keywords: online marketing, networking, World Wide Web, virtual enterprise, web marketing

Full Text 


\section{Regional Economic Development through Local Heritage, Knowledge, and Learning}

Wednesday, 20 June $2012 \cdot 16: 00-18: 00$

\section{Programme Moderator: Gregor Jagodič}

International School for Social and Business Studies, Slovenia

Forum on 'Regional Economic Development through Local Heritage, Knowledge and Learning' presents opportunities and strategies to promote and raise the profile of the region by emphasizing tradition and typical regional products and services. Special emphasis is put on a very successful project 'OTOP (One Town One Product),' which takes place in Thailand with the help of the King, and which is today recognized by tourists in Thailand at every step. By this project individual regions identify themselves through specific products and thus contribute to the visibility of the region. Parallel to the OTOP project the Network business incubator Vrelec in Rogaska Slatina (glassworks, tourism services, etc.) and the Centre for Development Litija and their project 'Heart of Slovenia' is also presented.

Wednesday, 20 June 2012

16.00

Dean's welcome - Dr. Srečko Natek, International School for Social and Business Studies, Slovenia

16.00-16.30 Presentation of »OTOP - One Town One Product» Dr. Pornthep Anussornnitisarn, Kasetsart University, Thailand

16.30-17.00 Ms Mojca Štepic, Centre for development Litija, Slovenia

17.00-17.30 Ms Branka Aralica, Business Incubator Vrelec d.o.o., Rogaška Slatina, Slovenia

\subsection{0-18.00 Discussion}

Pre-conference programme may be subject of change. The programme is free of charge for all MakeLearn and Doctoral Students' Workshop 2012 participants. 


\title{
Academic Writing for Publishing Scientific Papers in International Journals
}

Doctoral Students' Workshop • 22-23 June 2012

\author{
dr. Binshan Lin \\ College of Business Administration, Louisiana State University, USA
}

The workshop provides a great opportunity for doctoral students, young researchers and postdocs to gain new knowledge and skills on academic writing for publishing scientific papers in international journals. Workshop is implemented by internationally recognized scholar, prof. dr. Binshan Lin, BellSouth Corporation Professor in Business Administration at College of Business Administration, Louisiana State University, USA. It consists of presentation of scientific research process and strategy; structural equation modelling; enhancing relevance, quality, and impact of scientific research; one-to-one coaching; answering participants' questions and more.

Professor Dr. Binshan Lin is the BellSouth Corporation Professor at Louisiana State University in Shreveport. He received his Ph.D. from the Louisiana State University. Dr. Lin is a nine-time recipient of the Outstanding Faculty Award at LSUS. Professor Lin received the Computer Educator of the Year award by the International Association for Computer Information Systems (IACIS) in 2005, Ben Bauman Award for Excellence in IACIS 2003, Distinguished Service Award at the Southwest Decision Sciences Institute (SWDSI) in 2007, and Outstanding Educator Award at the SWDSI in 2004. He has published over 240 articles in refereed journals. He is Editor-in-Chief of Industrial Management \& Data Systems journal - the ISI Impact Factor 2009 of IMDS is 1.535 .

Friday, 22 June 2012

$\begin{array}{ll}13.00-14.00 & \text { Registration } \cdot \text { 2nd floor lobby } \\ 14.00-14.15 & \text { Welcoming remarks by ISSBS Dean dr. Srečko Natek } \cdot \text { Room B } \\ 14.15-17.00 & \text { Scientific research process and strategy } \cdot \text { Room B } \\ 17.00-17.30 & \text { Coffee break } \cdot 2 \text { nd floor lobby } \\ 17.30-19.00 & \text { Structural equation modelling }-1 \text { st part } \cdot \text { Room B } \\ 20.00 & \text { Dinner } \cdot \text { Hotel Štorman }\end{array}$

Saturday, 23 June 2012

9.00-10.30 Structural equation modelling -2 nd part $•$ Room B

10.30-11.00 Coffee break • 2nd floor lobby

11.00-13.45 Enhancing relevance, quality, and impact of scientific research • Room B

13.45-14.00 Closing remarks $\cdot$ Room $B$

15.00-17.00 City-tour Celje. Meeting point in front of ISSBS building. 


\section{International Journal Of Management, Knowledge and Learning}

ISSN 2232-5107 (printed) • ISSN 2232-5697 (online) • www.ijmkl.si

International Journal Of Management, Knowledge and Learning (IJMKL) aims to bring together the researchers and practitioners in business, education and other sectors to provide advanced knowledge in the areas of management, knowing and learning in organisations, education, business, social science, entrepreneurship, and innovation in businesses and others. It encourages the exchange of the latest academic research and provides all those involved in research and practice with news, research findings, case examples and discussions. It brings new ideas and offers practical case studies to researchers, practitioners, consultants, and doctoral students worldwide.

IJMKL is listed/abstracted in EconPapers.

IJMKL publishes original and review papers, technical reports, case studies, comparative studies and literature reviews using quantitative, qualitative or mixed methods approaches. Contributions may be by submission or invitation, and suggestions for special issues and publications are welcome. All manuscripts will be subjected to a double-blind review procedure.

Manuscripts should be double-spaced throughout and submitted via email attachment in MS Word format to Editor-in-Chief, Dr. Nada Trunk Širca at ijmkl@issbs.si with a brief bio sketch, 2-10 keywords and an abstract of approximately 50-100 words. For detailed instructions, please check the author guidelines at www.ijmkl.si. We do not process any submission that does not comply with IJMKL guidelines.

\section{Editor-in-Chief}

Dr. Nada Trunk Širca, International School for Social and Business Studies; Faculty of Management Koper, University of Primorska; and National Leadership School,

Slovenia

nada.trunk@guest.arnes.si, ijmkl@issbs.si

\section{Associate Editors}

Dr. Steve Kuang-Hsun Shih, Chinese Culture University, Taiwan

Dr. Zbigniew Pastuszak, Maria Curie-Skłodowska University, Poland

Dr. Pornthep Anussornnitisarn, Kasetsart University, Thailand

\section{Senior Editor}

Dr. Binshan Lin, BellSouth Professor, Business School, Louisiana State University in Shreveport, USA

\section{Executive Editor}

Dr. Valerij Dermol, International School for Social and Business Studies, Slovenia 


\section{International Journal of Management in Education}

ISSN 1750-385X • www.inderscience.com/ijmie

International Journal of Management in Education (IJMIE) aims to publish papers, which analyze all aspects of international education, researchers and professionals from education have the opportunity to discuss the most demanding issues regarding the development and leadership of education at all levels and in all areas of education management.

The IJMIE is indexed/listed in Academic OneFile, British Education Index, Business and Company Resource Center, Educators Reference Complete, Expanded Academic ASAP, General BusinessFile ASAP International, General OneFile, Google Scholar, InfoTrac Custom Journals, Scirus, and Cabell's Directory of Publishing Opportunities. The H-Index (based on Harzing's Publish or Perish software) of the IJMIE is 16. On average, there are 2.95 cites per published paper.

The IJMIE publishes 4 printed issues a year. A sample issue is available at http://www.inderscience.com/sample.php?id=201.

The IJMIE strives to provide constructive and developmental reviews to authors within approximately two months. To accomplish this objective, the IJMIE maintains a rapid electronic submission, review and publication process. On average, the double-blind review process for the IJMIE takes 6-8 weeks for an initial submission. The review process is designed to promote expedited reviews, developmental feedback, and a service culture of professionalism and collegiality. In the past 12 months, the IJMIE received more than 100 manuscripts. The current acceptance rate is $18 \%$.

You are kindly invited to submit papers. All papers should be submitted via email attachment in one single MS Word format file to me at dusan.lesjak@mfdps.si and ijmie@issbs.si. Please check our web site at http://www.inderscience.com/ijmie concerning the format, style, and guide to authors.

\section{Editor-in-Chief}

Dr. Dušan Lesjak, International School for Social and Business Studies, Slovenia dusan.lesjak@mfdps.si, ijmie@issbs.si

\section{Associate Editor}

Dr. Eddy Siong-Choy Chong, Linton University College, Malaysia

\section{Executive Editor}

Dr. Nada Trunk Širca, International School for Social and Business Studies; Faculty of Management Koper, University of Primorska; and National Leadership School, Slovenia 


\section{International Journal of Synergy and Research}

ISSN 2083-0025 • www.ijsr.umcs.lublin.pl

International Journal of Synergy and Research (IJSR) journal aims to provide a multidisciplinary platform for the advancement of knowledge in the areas of services, engineering, business, management, education and social sciences in the area of synergy. Synergy seems to be the main expected factor of different business and/or social activities in nowadays, networked, electronic, interconnected, real-time, knowledge-based economy.

The journal publishes original and review papers, technical reports, case studies and literature reviews using both quantitative and qualitative modelling techniques. Contribution may be by submission or invitation, and suggestions for special issues and publications are welcome.

Papers are solicited that address these issues from an empirical and/or conceptual point of view. Possible topics of interest include (but are not limited to): business science synergy, business education synergy, clusters synergy, intellectual capital synergy, knowledge management synergy, innovation synergy, human resources management synergy, cross culture management synergy, corporate synergy, service strategies synergy, service management synergy, information systems synergy, decision support systems synergy, e-business solutions synergy, total quality management synergy, marketing synergy, operations management synergy, virtual customer and organization synergy, customer relationship management synergy, supply chain synergy, production management synergy, finance synergy, sustainable economy synergy, international business synergy.

Manuscripts should be double-spaced throughout and submitted via email attachment in MS Word format to Editor, Dr. Zbigniew Pastuszak at z.pastuszak@umcs.lublin.pl with a brief biosketch, 1-10 keywords and an abstract of approximately 50-100 words. Please check our web site at www.ijsr.umcs.lublin.pl concerning the format, style, and guide to authors. Manuscripts could be original papers, empirical studies, literature and research reviews providing new perspectives, studies based on a synergy of sustainable economy, enterprise development, comparative studies, or case studies. Each paper submitted will be subjected to the double-blind review procedures of IJSR.

\section{Editor-in-Chief}

Dr. Agnieszka Sitko-Lutek, Maria Sklodowska-Curie University

agnieszka.sitko-lutek@poczta.umcs.lublin.pl

Senior Editor

Dr. Binshan Lin, College of Business Administration, Louisiana State University in Shreveport, USA

\section{Editor}

Dr. Zbigniew Pastuszak, Maria Sklodowska-Curie University, Poland 


\title{
International Journal of Innovation and Learning
}

ISSN 1471-8197 • www.inderscience.com/ijil

International Journal of Innovation and Learning (IJIL), a fully refereed journal, is an authoritative source presenting information on the current practice, content, technology, and services in the area of innovation and learning. IJIL aims to help professionals working in the field, academic educators and policy-makers to contribute, to disseminate knowledge, and to learn from each other's work.

IJIL is celebrating 6 years of publication. Furthermore, the IJIL is moving quickly towards higher publication standards. IJIL has been recognized and included in the following databases British Education Index, Educational Research Abstracts, Educational Technology Abstracts, Geobase, Google Scholar, Inspec, Library and Information Science Abstracts (LISA), Pascal, Scirus, Scopus. The IJIL is listed in the Cabell's Directory of Publishing Opportunities and is accepted in many universities for credit towards tenure and promotion.

Subject coverage: accounting systems and it security in e-learning environment, collaborative leaning/collaborative product design, continuous improvements, corporate communications and learning, cross-cultural issues in e-learning, design thinking, distance learning models and strategies, dynamics of innovation and leaning/innovation-driven learning, e-learning group support systems and learning, improving the breadth and quality of access, incubation process/ innovation process and strategy, innovation and learning in biotech industry, innovative environmental management, innovation and business intelligence, intellectual capital and properties, km systems and value creation/knowledge sharing, knowledge-building community/knowledge management, leadership in knowledge-based society, lean manufacturing learning and instructions, learning design, machine learning, management innovation, media richness theory, mind maps, mobile learning, multimedia synchronization controls, new product development, online learning/online collaboration, online communities/virtual communities, open source and new learning models, organizational blogs and knowledge sharing, organizational learning and knowledge creation, production planning, resource-based learning and innovation, retention in online learning, rfid: innovative strategy, semantic web for e-learning, simulation games by design, standards and standardization in innovation process, technological standardization in innovation and learning, technology transfer, total quality management, unlearning and learning for technological innovation, virtual collaboration in the workplace, web-based km planning, web services innovation.

\author{
Editor-in-Chief \\ Dr. Kongkiti Phusavat, Faculty of Engineering, \\ Kasetsart University, Thailand \\ fengkkp@ku.ac.th
}




\section{International Journal of Performance Measurement}

ISSN 2165-6371 • http://performancesforum.org/index.html

International Journal of Performance Measurement (IJPM) aims to publish the advancement of knowledge papers in several fields, the refereed articles covering both theoretical and applied aspects of performance measurement and its application. We consider about how to establish the Performance Measurement and its application in business, economics, education, engineering, finance, information technology, marketing, management, operation research, public affairs and all kind of subjects that involve the Performance Measurement. Performance measurement is a multidisciplinary theory gathering the strength of those researches which were interested in utilizing different research techniques to investigate the related performance measurement areas. The Journal was supposed to be established as an authoritative journal, which publish the high quality articles from people all over the world who are interested in the research of performance measurement. Refereed \& Cabell Indexed.

The IJPM is the official publication of the Academy of Performance Measurement published on a semiannually basis, and will be extended to a quarterly basis before 2014. The Journal is a refereed publication containing articles related to Performance Measurement research including innovative and advanced knowledge. The guidelines that must be followed when submitting a manuscript to be reviewed for publication can be retrieved in the official website. Manuscripts must be word processed and electronically submitted as a Word document attached to an e-mail to Editor-in-Chief: Professor Steve Kuang-Hsun Shih at theijpm@gmail.com. Hard copy submissions will not be accepted.

\section{Editor-in-Chief}

Dr. Steve Kuang-Hsun Shih, Chinese Culture University, Taiwan

theijpm@gmail.com, shihsteve@faculty.pccu.edu.tw

Associate Editor

Dr. Agnieszka Sitko-Lutek, Maria Sklodowska-Curie University, Lublin, Poland Dr. Nada Trunk Širca, International School for Social and Business Studies; Faculty of Management Koper, University of Primorska; and National Leadership School,

Slovenia

Senior Editor

Dr. Binshan Lin, College of Business Administration, Louisiana State University in Shreveport, USA

Managing Editor

Dr. Shu-Hsien Lin, Chinese Culture University, Taiwan 


\section{International Journal of Business Development and Research}

www.bus.ku.ac.th/journal

International Journal of Business Development and Research (IJBDR) is a fully refereed journal with editorial members from various countries. The journal aims to present relevant information on current and emerging practices in business and industry as well as research in the areas of business innovation, applied technologies, and industrial \& organizational management. IJBDR intends to assist professionals, researchers, educators, and policy-makers to disseminate knowledge and to learn from each other's work.

IJBDR will publish at least 2 issues a year, both in printed and electronic formats. One issue contains 5-7 articles. Submissions should follow the author guidelines which can be found at www.bus.ku.ac.th/journal.

Subject areas: accounting practices, activity-based costing, life-cycle costing, and cost of quality, acquisition logistics - life-cycle design, commonality, and interchangeability, business strategy development and deployment, collaborative supply chain management, commercial logistics - computer applications, warehouse and inventory, and transportation and distribution, customer delight and loyalty, customer relations and management, emerging new practices in business \& industry, enterprise planning and development, enterprise resources planning and integration, finance and cost of capital consideration, innovation management, it applications in operational management, incubation and smes development, intellectual capital and properties, investment framework and decisions, knowledge management, lean manufacturing, life-cycle management, management system design and analysis, manufacturing and operational strategies, marketing and business development, new product/ service design and development, organizational management and development, performance management, quality and productivity measurement, analysis, and improvement, risk management, technology management, technology transfer, total quality management, social marketing, sustainability, value-chain and supply-chain management, web-based services.

To submit a manuscript or for further information, please contact the Editor-in-Chief, Dr. Haruthai Numprasertchai, at haruthai.p@ku.ac.th.

\section{Editor-in-Chief}

Dr. Haruthai Numprasertchai, Kasetsart University, Thailand haruthai.p@ku.ac.th 


\section{Index}

Adam, Jean-Michel, 27

Agunloye, Olajide O., 34

Alanezi, Abdullah, 29

Anussornnitisarn, Pornthep, 4, 21

Aristovnik, Aleksander, 22

Babnik, Katarina, 29

Bal, Yasemin, 33

Balogh, Ágnes, 17, 18

Bencsik, Andrea, 28

Bogdány, Eszter, 17, 18

Bojanc, Rok, 34

Bojnec, Štefan, 10, 30

Borangic, Daniela, 32

Boroń, Dominika, 26

Bouziane, Zaid, 4

Bozkurt, Serdar, 33

Brejc, Mateja, 10

Brence, leva, 27

Breßler, Julia, 23

Breznik, Kristijan, 21, 29

Brustureanu, Bogdan, 32

Burčik, Vladimir, 27

Carvalho Wilks, Daniela de, 5

Chalupova, Martina, 25

Chan, Cliff C.H., 16

Chen, Chien-Nan, 19

Cichorzewska, Marzena, 18

Cizmadia, Tibor, 17

Csibi, Erzsebet, 13

Csizmadia, Tibor, 18

Cuypers, Marc, 23

Čančar, Ivana, 28

Čuček, Andrej, 35

Dahbi, Mohamed, 4

De Alwis, Chamaru, 20

Dermol, Valerij, 4, 9, 13, 20

Dickov, Veselin, 17

Djordjević Boljanović, Jelena, 15

Dobrai, Katalin, 23

Draghici, Anca, 4, 26

Dulčić, Željana, 30
Dyck, Harold, 17

Dzunić, Marija, 15

Đaković, Goran, 5

Đonlagić, Sabina, 24

Ertemsir, Esin, 33

Fan, Jin-Jun, 22

Farkas, Ferenc, 23

Fekete, Milan, 23

Feng, Hsiang-Yung, 22

Frankó, Krisztina, 19

Fülöp, Gyula, 17

Gačnik, Aljoša, 35

Geertshuis, Susan, 30

Gordon, Linda C., 17

Gorenak, Irena, 23

Gorenak, Mitja, 19

Goriup, Jana, 29

Grabar, Urška, 35

Grela, Grzegorz, 16

Grubor, Aleksandar, 30

Harapin, Nina, 26

Hofman, Mariusz, 16

Horváth, Zsuzsanna, 24

Hozjan, Dejan, 4

Hódi Hernádi, Bettina, 17

Hölzle, Katharina, 31

Hren, Saša, 35

Ingram, Tomasz, 29

Jager, Božidar, 34

Jagodič, Gregor, 21

Jaithat, Pairin, 21

Jakubiak, Monika, 27

Janeš, Aleksander, 33

Jayawardena, L.N.A. Chandana, 24

Jayawardena, L.N.A. Ishanthi, 24

Jonek-Kowalska, Izabela, 32

Jóźwik, Bartosz, 30

Justinek, Gorazd, 10, 31

Juszczyk, Marta, 34

Kadeřábková, Tereza, 22

Kajdiž, Romana, 30

\section{4}


Karaschewitz, Aiko, 31

Karasek, Aneta, 31

Kmieciak, Roman, 15

Kočevar, Mia, 5

Kohun, Frederick G., 27

Kolenc, Katja, 5

Koohang, Alex, 9, 10, 33, 34

Koren, Andrej, 4, 9, 10

Košir, Suzana, 19, 26

Kovač Žnideršić, Ružica, 30

Kovač, Matjaž, 35

Krickl, Otto, 30

Kung, David S., 17

Kurtić, Adil, 24

Lakis, Juozas, 29

Lazović, Svetlana, 35

Lesjak, Dušan, 4, 10, 27

Leszczynska, Agnieszka, 4, 18

Lešnik, Leon, 35

Lin, Binshan, 4, 10, 13

Lipowski, Marcin, 26

Loboda, Miroslaw, 4

Lorber, Lučka, 10

Lujan Mora, Sergio, 27

Maniecki, Maciej, 7, 13

Marić, Dražen, 30

Marjeta Rukav, 35

Markiewicz, Piotr, 21

Martins, Simone, 26

Mącik, Radosław, 4, 16, 30

Meeampol, Sasivimol, 10, 21

Menrad, Martin, 28

Meža, Peter, 15

Michna, Anna, 15

Mifsud, Joseph, 9

Mikačić, Ivana, 30

Miklošíková, Zuzana, 23

Miłosz, Elżbieta, 27

Miłosz, Marek, 27, 34

Mlaker Kač, Sonja, 23

Mohor, Saša, 35

Mohorko, Jasmina, 5

Moustaghfir, Karim, 4, 9, 28
Nalewajek, Monika, 16, 30

Natek, Srečko, 3, 4, 9, 13

Németh, Krisztina, 32

Németh, Szilárd, 32

Nogalski, Bogdan, 24

Norek, Tomasz, 15

Novak, Matija, 12

Numprasertchai, Haruthai, 4, 10

Olariu, Cristian, 26

Ostad Ali Naghi Kashani, Mohammad Reza, 18

Otręba, Rafał, 19

Padjan, Denis, 35

Paliszkiewicz, Joanna, 11, 17

Papić, Anita, 15

Pasnicu, Daniela, 4

Pastuszak, Zbigniew, 4, 11

Paździor, Artur, 16

Paździor, Maria, 16

Pejić, Vaska, 23

Pezdir, Rado, 12

Phusavat, Kongkiti, 4, 9, 11

Piasecka, Agnieszka, 16

Plivac Kolar, Dragica, 35

Podmenik, Darka, 28

Polák-Weldon, Réka, 17, 18

Popescu, Tudorel, 32

Potočnik Mesarić, Tanja, 25

Pravilović, Sonja, 22

Radović, Ognjen, 33

Rakowska, Anna, 5, 12, 18

Rassameethes, Bordin, 4, 9, 12, 21

Rivza, Baiba, 27

Rueangsuwan, Sarayut, 21

Sachakamol, Punnamee, 20

Salai, Suzana, 30

Santos, Jorge, 26

Saxunova, Darina, 20

Scarlat, Cezar, 5, 9, 32

Sebastio, Augusto, 32

Sedej, Tanja, 31

Seitz, Christian, 29

Serwach, Tomasz, 22 
Setnikar Cankar, Stanka, 31

Shih, Steve Kuang-Hsun, 9, 11

Sitko-Lutek, Agnieszka, 5, 9, 11, 27

Skovira, Robert Joseph, 16, 27

Skrbinjek, Vesna, 27

Skrzypek, Elżbieta, 16

Skrzypek, Elzbieta, 5

Skurzynska-Sikora, Urszula, 5, 22

Smrkolj, Marko, 5

Sooksmarn, Suparerk, 11, 21

Spalek, Seweryn, 5, 25

Stanković, Jelena, 33

Stričević, Ivanka, 15

Subotić, Jana, 15

Svatošová, Veronika, 15

Szołtysek, Jacek, 19

Škrabl, Anton, 12

Šoba, Vilma Alina, 29

Štrajn, Darko, 11

Švec, Václav, 22

Tang, Esther P.Y., 16

Tao, Nancy R., 17

Tat, Ute, 25

Tavčar, Mitja I., 12

Thurner, Stefan, 28

Tichá, Ivana, 22

Tímea, Juhász, 28

Toplišek, Franci, 35

Touhami, Abdouli, 5

Tripes, Stanislav, 16

Trunk Širca, Nada, 4, 11, 27, 29

Tsai, Yuh-Yuan, 19

Tseng, Chin-Li, 19

Turk, Darja, 13

Twaróg, Sebastian, 19

Uricchio, Antonio, 9

Vodopivec, Milan, 8, 14

Voracek, Jan, 16, 19

Vukasovič, Tina, 30

Wallner, Thomas, 28

Wattananusornand, Jiravut, 21

Wąsowska, Katarzyna, 20

Wereda, Wioletta, 24
Wiechetek, Łukasz, 33

Wronka, Martyna, 25

Yam, Richard C.M., 16

Zeitel-Bank, Natascha, 25

Zelena, Veronika, 19

Zinczuk, Bartłomiej, 5, 18

Zsakay, Gábor, 28

Zupanc, Darko, 9

Žabić, Danijel, 5

Žižmond, Egon, 5, 11

\section{6}




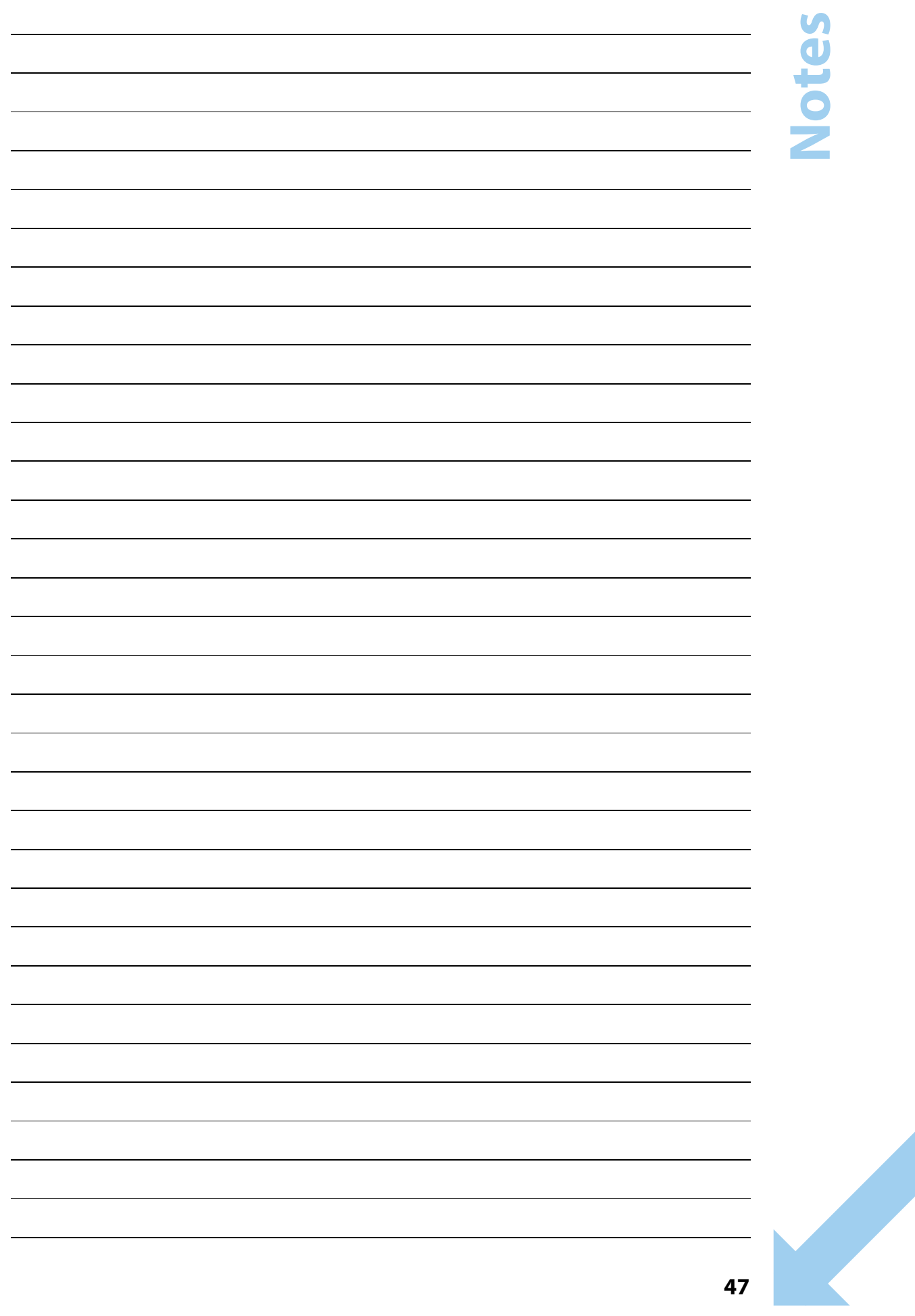


(1) 


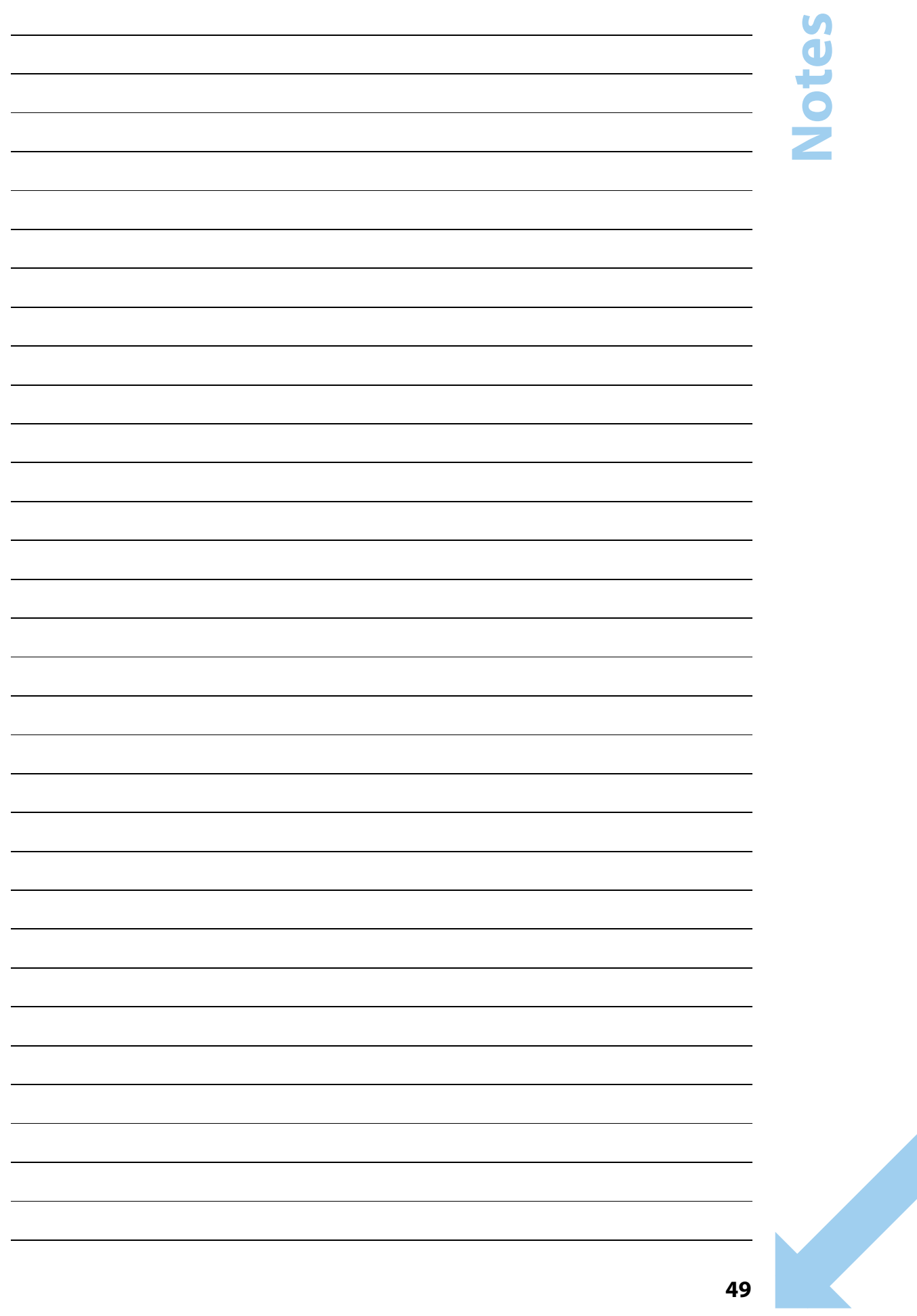




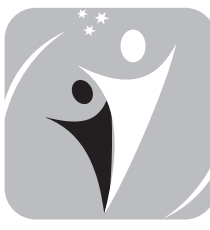

Mednarodna fakulteta

za družbene in poslovne študije

International School

for Social and Business Studies

Celje $\cdot$ Slovenija
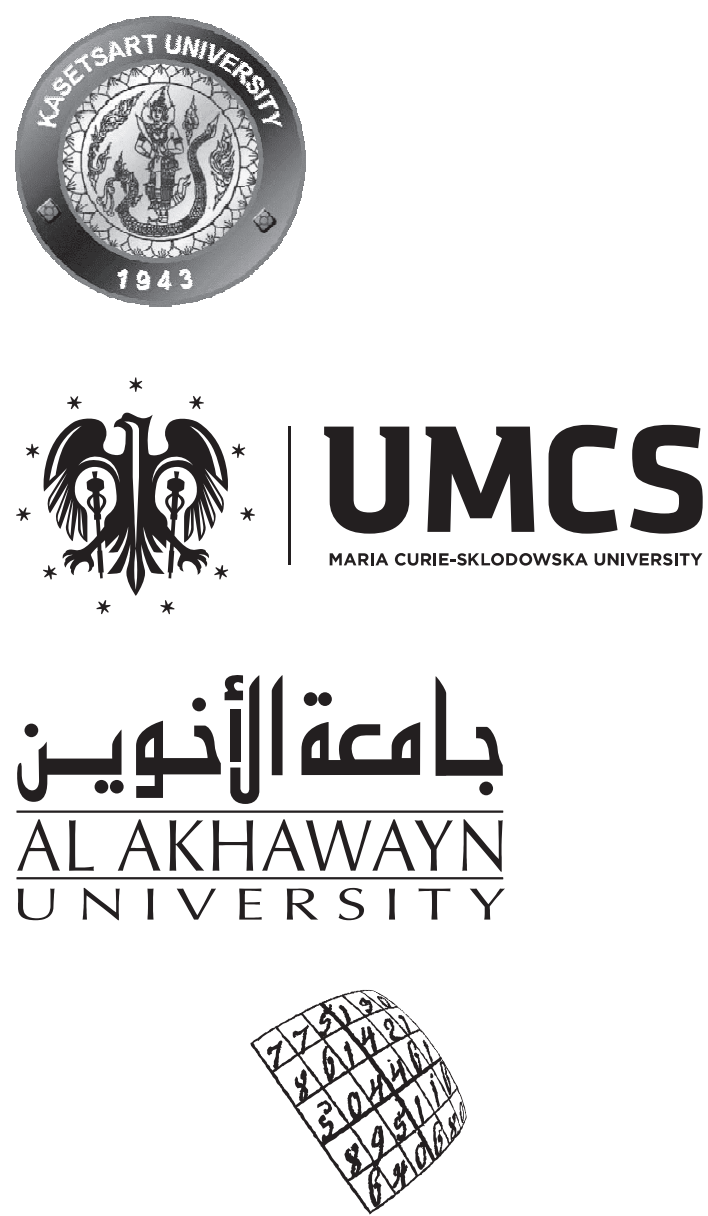

SLOVENIAN RESEARCH AGENCY 


\section{Active Citizenship by Knowledge Management \& Innovation}

Management, Knowledge and Learning International Conference 2013

19-21 June 2013

\section{Zadar • Croatia}

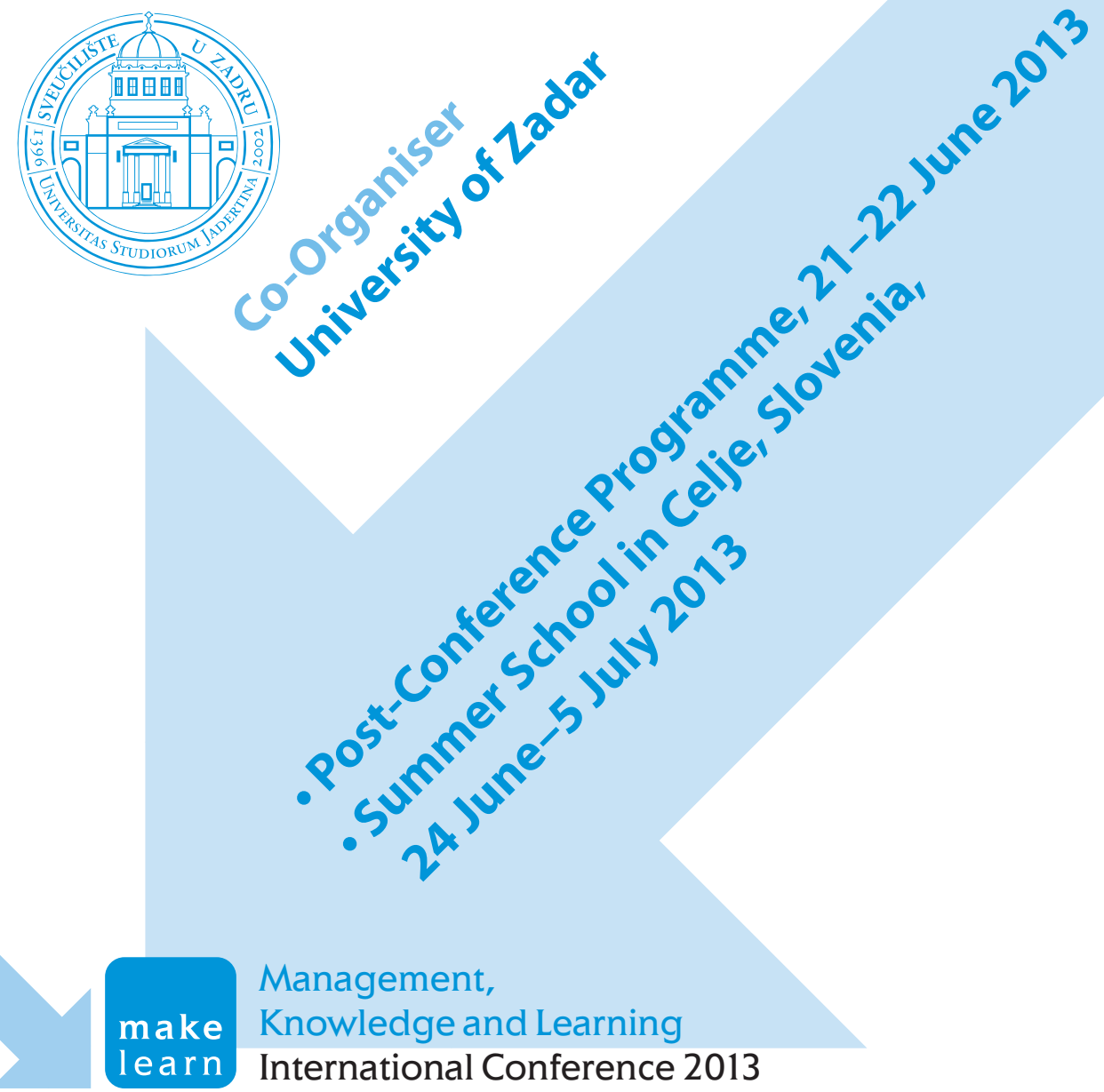


The International Scientific Conference on Management of Knowledge and Learning (MakeLearn) is organised by the International School for Social and Business Studies (ISSBS) in cooperation with foreign partner universities, international institutes and organisations chosen in accordance with its annual theme. The conference takes place every June; its participation is international. The official language of the conference is English.

Through MakeLearn, the ISSBS encourages the sharing of most recent developments in the field of knowledge management between Slovene and foreign experts, as well as promotes itself and higher education in the Savinja region of Slovenia and Europe. By including individuals from major regional businesses, MakeLearn also encourages discussion and the exchange of knowledge between the academia and the economy. Although the general theme of the conference, i.e. management of knowledge and learning in businesses and other organisations, remains the same, each year the focus of the conference is adapted to regional and global findings, occurrences and needs of the time.

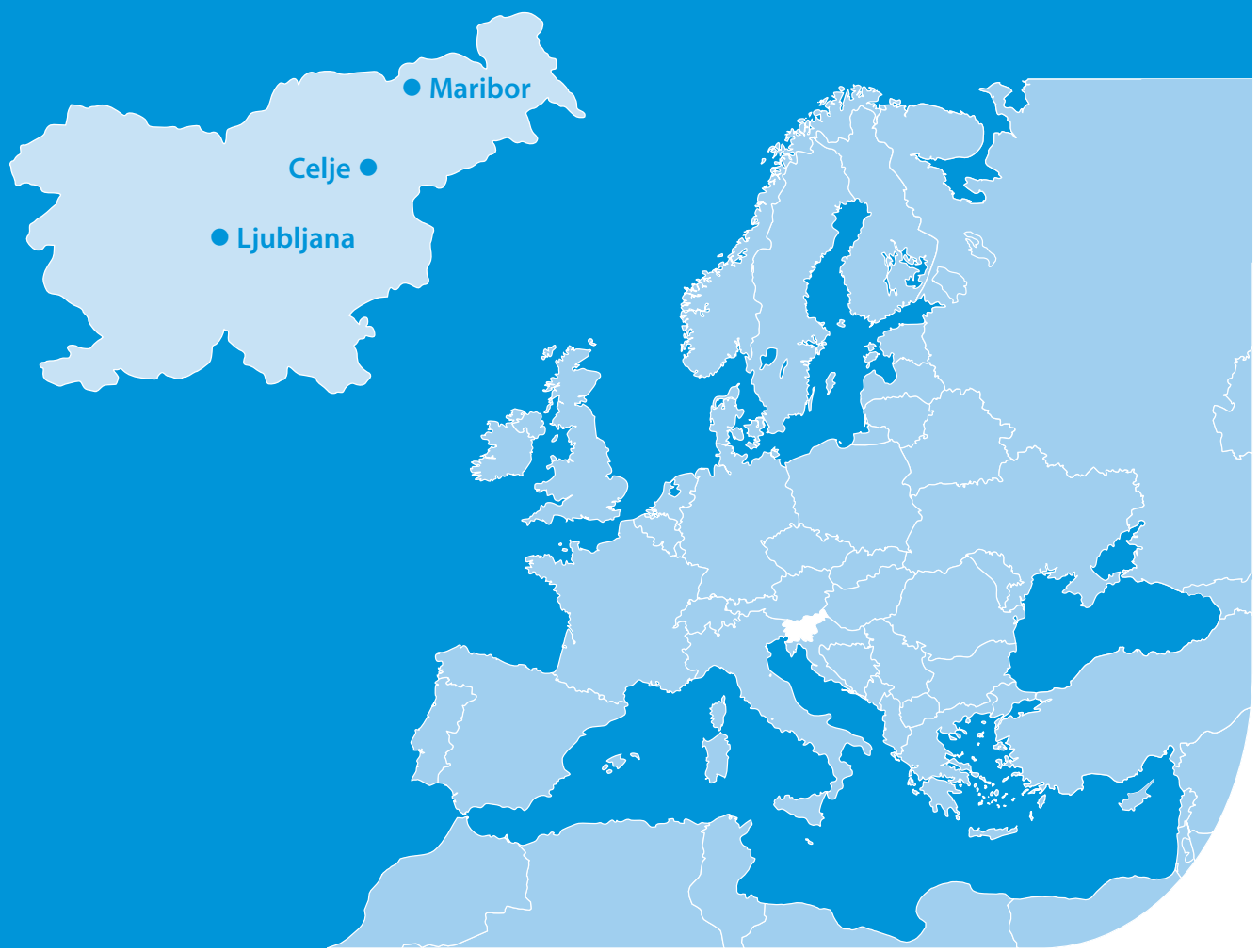

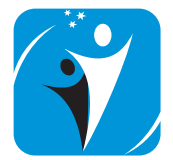

Mednarodna fakulteta za družbene in poslovne študije International School for Social and Business Studies Celje $\cdot$ Slovenija
International School for Social and Business Studies Mariborska cesta 7, 3000 Celje, Slovenia

Tel: +386342582 40 • Fax: +386342582 22

E-mail: info@mfdps.si •http://www.mfdps.si/en 